\title{
JURISPRUDENCIA AMBIENTAL EN LAS ISLAS BALEARES \\ (SEGUNDO SEMESTRE 2016)
}

\author{
p. $1-30$
}

\section{JURISPRUDÈNCIA AMBIENTAL A LES ILLES BALEARS (SEGON SEMESTRE 2016)}

\author{
p. 31-59 \\ JosÉ MANUEL GÓMEZ GONZÁLEZ \\ Assessor jurídic del Servei d'Ordenació del Territori \\ Departament de Territori i Infraestructures \\ Consell Insular de Mallorca
}

\begin{abstract}
Sumario: 1. Sobre la responsabilidad patrimonial derivada de modificaciones de la normativa urbanística en suelos urbanizables: la Sentencia del Tribunal Superior de Justicia de las Islas Baleares (número 401/2016) de 5 de julio de 2016 (Id. Cendoj: 07040330012016100349, núm. procedimiento PO 190/2012 - Rollo Sala 123/2016). 2. Sobre responsabilidad patrimonial derivada de una anulación judicial de licencia de obras: la Sentencia del Tribunal Superior de Justicia de las Islas Baleares (número 412/2016) de 7 de julio de 2016 (Id. Cendoj: 07040330012016100376, núm. procedimiento PO 175/2011 - Rollo Sala 381/2015). 3. Sobre la obligatoriedad de construir una pantalla acústica en una carretera: la Sentencia del Tribunal Superior de Justicia de las Islas Baleares (número 455/2016) de 14 de septiembre de 2016 (Id. Cendoj: 07040330012016100413, núm. procedimiento PO 059/2012 - Rollo de la Sala 129/2016). 4. Sobre obras ilegales y órdenes de demolición: la Sentencia del Tribunal Superior de Justicia de las Islas Baleares (número 405/2016) de 6 de julio de 2016 (Id. Cendoj: 07040330012016100370, núm. procedimiento PO 013/2010 - Rollo de la Sala 178/2016). 5. Sobre imputación de gastos por ejecución subsidiaria: la Sentencia del Tribunal Superior de Justicia de las Islas Baleares (número 422/2016) de 12 de julio de 2016 (Id. Cendoj: 07040330012016100358, núm. procedimiento PO 179/2012 - Rollo de la Sala 203/2016). 6. Sobre restitución de la legalidad urbanística y de la realidad física alterada: la Sentencia del Tribunal Superior de Justicia de las Islas Baleares (número 439/2016) de 26 de julio de 2016 (Id. Cendoj: 07040330012016100383, núm. procedimiento PO 187/2012 - Rollo de la Sala 061/2016).
\end{abstract}


Examinadas las sentencias en el campo del derecho ambiental del segundo semestre del 2016, vemos que no se han generado resoluciones de un interés especial. En este número hemos destacado seis resoluciones que, salvo una relativa a contaminación acústica y otra sobre protección de espacios naturales de especial protección, se centran básicamente en temas de disciplina urbanística y de responsabilidad patrimonial por la adopción de medidas de protección territorial.

Por una parte, puede tener cierto interés la Sentencia del Tribunal Superior de Justicia de las Islas Baleares (número 455/2016) de 14 de septiembre de 2016, relativa a la obligatoriedad o no de mitigar los efectos de la contaminación sonora por el hecho de construir una nueva infraestructura viaria que provoca emisiones e inmisiones superiores a las previstas en la legislación relativa a la protección frente al ruido. La pregunta planteada es si en suelo rústico también surge este deber de mitigar la contaminación sonora y hasta qué punto debe ser resuelto el problema por la Administración que construyó la carretera.

Por otra, la denegación del derecho de recibir una indemnización por responsabilidad patrimonial se manifiesta en dos sentencias de sentido contrapuesto, una que confirma la aplicación correcta de la normativa de protección territorial amparada en la posibilidad de adoptar una sucesiva serie de instrumentos de mayor protección, y otra que condena a pagar como consecuencia de una deficiente actuación municipal por el otorgamiento de una licencia que fue anulada por no ajustarse a derecho.

Las restantes sentencias tratan sobre temas de control de la legalidad urbanística: una sobre el margen y el límite que condicionan la adopción o no de medidas cautelares ante casos de órdenes de demolición como consecuencia de dicho control disciplinario; y otras dos sobre la misma materia: órdenes de demolición y ejecución subsidiaria por parte de la Administración que corren distinta suerte.

Pasemos a continuación a analizar las sentencias seleccionadas. 
1. Sobre la responsabilidad patrimonial derivada de modificaciones de la normativa urbanística en suelos urbanizables: la Sentencia del Tribunal Superior de Justicia de las Islas Baleares (número 401/2016) de 5 de julio de 2016 (Id. Cendoj: 07040330012016100349, núm. procedimiento PO 190/2012 - Rollo Sala 123/2016)

La sentencia que traemos a análisis juzga el caso de una reclamación de responsabilidad patrimonial derivada de una modificación de planeamiento en un área perteneciente a un antiguo plan parcial que fue desclasificado y considerado suelo rústico. Más concretamente, se atacó la Resolución del conseller de Urbanismo y Territorio del Consell Insular de Mallorca de 25 de julio de 2012 en la que se inadmite por improcedente la reclamación de responsabilidad patrimonial formulada por el reclamante el 25 de abril de 2012 respecto a la aprobación cinco años antes (el 26 de abril de 2007) de las Normas Subsidiarias de Andratx (Mallorca), en las que aparecían clasificadas como suelo rústico una serie de parcelas que habían pertenecido al ámbito del Plan Parcial de Urbanización de la Costa de Andratx. Este plan parcial se había aprobado el 13 de enero de 1975 (sin que llegara a consolidarse completamente). A su vez, las parcelas objeto de discusión habían sido adquiridas en 1997 por el demandante al precio de 9 euros $/ \mathrm{m}^{2}$.

Para ampliar el caso, recordaremos que en el momento de la compra (en 1997) esas parcelas ya tenían la clasificación de suelo rústico protegido, en concreto a raíz de la Ley 1/1991, de 30 de enero, de espacios naturales y de régimen urbanístico de las áreas de especial protección de las Islas Baleares (LEN), en vigor desde el 10 de marzo de 1991. La Administración apelada, el Consell Insular de Mallorca, aprobó definitivamente el Plan Territorial Insular de Mallorca el 13 de noviembre de 2004, que tenía que sujetarse a la LEN y, por lo tanto, mantuvo la desclasificación. A su vez, la Comisión de Ordenación del Territorio Urbanismo y Patrimonio Histórico del Consell Insular de Mallorca (CIOTUPH) aprobó definitivamente las Normas Subsidiarias de Andratx el 26 de abril de 2007, donde esas parcelas aparecieron con dicha clasificación, es decir, como suelo rústico protegido. Ello conduce a afirmar (como hace el Tribunal) que no fueron ni el Plan Territorial Insular de Mallorca de 2004 ni las Normas Subsidiarias de 2007 los instrumentos que clasificaron como suelo rústico las tres parcelas del demandante. Esas tres parcelas ya eran suelo rústico antes de su adquisición, como hemos visto, a un precio propio de suelo en situación rural.

No obstante, el recurrente siguió sustentando que la clasificación de sus parcelas era suelo urbano. Por ello, instó recurso en sede jurisdiccional, que vio desestimado en la Sentencia 
de la Sala núm. 258/2011, de 14 de abril de 2011 -ROJ: STSJ BAL 294/2011 - ECLI: ES: TSJBAL: 2011:294- Es evidente que, siendo pacífico que la Sentencia de la Sala núm. 258/2011 es firme, el ahora apelante debió aceptar en ese momento que las parcelas que había adquirido eran suelo clasificado como rústico protegido, pero no fue así y, aireando la idea de que diversas certificaciones administrativas recogían como urbanos los terrenos de su propiedad, afirma que compró inducido por un error y que ello debería ser compensado económicamente por la Administración. Así, con esta pretensión, más de un año después de la Sentencia de la Sala núm. 258/2011, en concreto el 25 de abril de 2012, presentó ante el Consell Insular de Mallorca una reclamación de responsabilidad patrimonial sin concretar qué indemnización pretendía, limitándose a afirmar que ya presentaría la valoración en un momento ulterior.

La Resolución del conseller de Urbanismo y Territorio del Consell Insular de Mallorca de 25 de julio de 2012 inadmitió por improcedente la reclamación de responsabilidad patrimonial formulada el 25 de abril de 2012. El recurrente instó la controversia en el Juzgado núm. 1, donde vio desestimado su recurso. El Juzgado estimó que las certificaciones a las que alude el reclamante eran de fecha posterior a la fecha en que compró las tres parcelas, lo que no casa con la idea de que le hubieran podido inducir a error alguno en el momento de la compra.

La sentencia del Juzgado fue recurrida en apelación, y en la demanda el reclamante aprovechó para introducir motivos de oposición a la decisión administrativa que no le habían sido mostrados a la juez ni en la demanda ni en las conclusiones. Tales detalles apuntan a que con la aprobación de las Normas Subsidiarias la superficie protegida pasa a ser mayor que en la LEN y en el PTIM. Como es natural, esos motivos no han podido ser tratados en la sentencia apelada.

En la demanda de 20 de diciembre de 2012, puede verse que, inexplicablemente, no se solicitó al Juzgado ni que se estimase el recurso ni que se anulase la resolución administrativa que se recurría. Lo que se solicitaba al Juzgado era una indemnización que no se concretaba "[...] por los actos realizados, que materializaban el aprovechamiento urbanístico [...]". Y esa petición se realizaba después de otra que consistía en que el Juzgado tendría que declarar en la sentencia que la clasificación de los terrenos del reclamante como suelo rústico protegido en las Normas Subsidiarias de 2007 y en el Plan Territorial Insular eran “[....] contrarias a la calificación contemplada en la Ley de Espacios Naturales [...]”. Sin embargo, hemos visto que en 2012 este era un tema cerrado 
ya que la clasificación de los terrenos del caso como suelo rústico protegido no se produjo ni con las Normas Subsidiarias de 2007 ni con el Plan Territorial Insular, donde se refleja la clasificación que impuso en 1991 la LEN, por lo que, por supuesto, tampoco cabía ya sostener que fueran " [....] contrarias a la calificación contemplada en la Ley de Espacios Naturales [...]".

El núcleo final del razonamiento del Tribunal Superior es el siguiente:

[...] En la apelación se expresa la idea de que la sentencia apelada no ha entendido qué es lo que el Sr. José Daniel quiere y, debido a ello, se considera que la sentencia ahora apelada no ha acertado con la respuesta apropiada al caso del Sr. José Daniel. La Sala no comparte esa idea del Sr. José Daniel. Consideramos que es el apelante el que no ha entendido la sentencia apelada, que le responde directa y claramente a sus pretensiones. Y lo hace para rechazarlas, en primer lugar, porque no tomaban en cuenta lo que debían, es decir, la sentencia de la Sala n 258/2011; y, además, porque las certificaciones a las que viene aludiendo el Sr. José Daniel eran de fecha posterior a la fecha en que compró las tres parcelas.

Como es natural, no puede ser aceptado en modo alguno que actos posteriores a la compra puedan haber inducido al Sr. José Daniel a error en esa compra.

Por lo tanto, la Sala acepta la decisión de la sentencia apelada y acepta la base jurídica que la sustenta.

Puede señalarse igualmente que, siendo el plazo para reclamar el de un año, ni que decir tiene que había transcurrido ya sobradamente el 25 de abril de 2012 no solo respecto a la Ley CAIB 1/191 y el Plan Territorial de 2004, sino también respecto a las Normas Subsidiarias de 2007.

Llegados a este punto, cumple la desestimación de la apelación.

Por todo ello, el Tribunal desestima el recurso contencioso-administrativo e indirectamente reconoce la capacidad de la LEN, del PTIM y de las Normas Subsidiarias de Andratx para establecer un bloque normativo consolidado no atacable que no da derecho a ningún tipo de indemnización con respecto a determinadas medidas de protección de suelos no consolidados procedentes de planes parciales no ejecutados, suelos que se convirtieron en zonas de protección especial. 


\section{Sobre responsabilidad patrimonial derivada de una anulación judicial de licencia} de obras: la Sentencia del Tribunal Superior de Justicia de las Islas Baleares (número 412/2016) de 7 de julio de 2016 (Id. Cendoj: 07040330012016100376, núm. procedimiento PO 175/2011 - Rollo Sala 381/2015)

El caso que presentamos en segundo lugar tiene como objeto la resolución dictada, de forma presunta por la ficción legal del silencio administrativo, por el Ayuntamiento de Sant Lluís (Menorca) que desestima la solicitud de responsabilidad patrimonial efectuada por el reclamante el día 10 de febrero de 2009.

En el presente caso el Ayuntamiento de Sant Lluís otorgó licencia en fecha 3 de junio de 2004 para la construcción de una vivienda anexa a explotación agraria. Dicha licencia fue objeto del recurso contencioso-administrativo núm. 127/2004, que finalizó por la Sentencia núm. 64/2006, de 2 de marzo de 2006, posteriormente confirmada por el Tribunal Superior de Justicia. La licencia fue anulada, lo que conllevó que se anularan también sus efectos, en los términos siguientes:

PRIMERO: Se estima el recurso contencioso administrativo interpuesto por D. Guillem Mercadal Gonyalons contra el Acuerdo de la Comisión de Gobierno del Ayuntamiento de Sant Lluis de 3 de junio de 2004 que concedió licencia para la construcción de una vivienda aneja a una explotación agrícola en la CARRETERA000 polígono NUM000 parcela NUM001.

SEGUNDO: Se declara nulo el acto administrativo impugnado por no ser ajustado al ordenamiento jurídico. [Sentencia núm. 64/2006, de 2 de marzo de 2006].

Con estos datos incontrovertidos a la vista de la sentencia mencionada, parece obvio que solo se puede concluir que el daño que reclama el recurrente no es indemnizable por cuanto no es antijurídico, en el sentido de que el recurrente tiene el deber de soportarlo al haber construido la mencionada vivienda cuando ya existía un recurso contenciosoadministrativo pendiente por resolver que tenía por objeto la anulación de la licencia; tal anulación era perfectamente posible, lo que implica que el riesgo fue asumido simplemente por el reclamante de responsabilidad patrimonial. Y es que, en efecto, el recurso contencioso se inició en el año 2004; así que, ya se tome la fecha de inicio de obras indicada por el recurrente —noviembre de 2005- o la señalada por el Ayuntamiento demandado - enero de 2006-, ya pendía el mencionado recurso. A mayor abundamiento, cuando las obras se encontraban en su inicio se dictó sentencia que anulaba la licencia, por lo que no se entiende la razón por la que el recurrente decidió 
continuar con las obras iniciadas ante la falta de apariencia de buen derecho en el otorgamiento de esta. Además, el Consorcio para la protección de la legalidad urbanística en suelo rústico de la isla de Menorca inició también en 2006 un expediente de restauración de la legalidad urbanística para la demolición de las obras de edificación realizadas por el recurrente.

Por todas estas razones, tanto el Juzgado de instancia como el TSJIB podrían haber apreciado culpa exclusiva de la víctima en la producción del daño relativo al coste de lo construido y el coste de la restauración del terreno al estado de origen, que rompe el nexo causal exigido para el nacimiento de la responsabilidad patrimonial del Ayuntamiento de Sant Lluís en relación con dichos daños. Sin embargo, como veremos a continuación, ello no ha sido así al modificarse el razonamiento en un doble sentido, primero por el Juzgado y luego por el TSJIB.

Efectivamente, el Juzgado de instancia apreció que cabía existencia de responsabilidad patrimonial de la Administración demandada en cuanto a los gastos necesarios para el otorgamiento de la licencia que efectivamente se concedió (coste del proyecto básico, del proyecto de ejecución, etcétera) y que, como hemos visto, fue anulada posteriormente en virtud de sentencia.

La cronología de los hechos sería la siguiente:

El día 21 de octubre de 2008 el reclamante presentó sendos escritos de reclamación de responsabilidad patrimonial solidaria en las sedes administrativas del Consell Insular de Menorca y del Ayuntamiento de Sant Lluís. La referida solicitud de responsabilidad patrimonial al Ayuntamiento de Sant Lluís fue desestimada por la ficción legal del silencio administrativo. Posteriormente se interpuso el recurso contencioso el día 28 de junio de 2011 con la petición de indemnización de 1.862.149,68 euros por la anulación de la licencia de obras y de 177.900 euros como cifra estimativa por los gastos previstos de demolición, en el supuesto de que él se tuviera que hacer cargo del abono de la ejecución, así como de cualquier otro gasto producido por la construcción y ahora demolición de la vivienda.

Tal reclamación se amparaba en el hecho de que, otorgada una licencia de obras para la construcción de una vivienda aneja a explotación agrícola por parte del Ayuntamiento de Sant Lluís, esta fue anulada después judicialmente, como ha quedado patente por la transcripción parcial de la sentencia de instancia efectuada anteriormente. 
La existencia de un procedimiento bifásico, dadas las características descritas de la solicitud, determinó la petición el mes de noviembre de 2003 de un informe vinculante al Consell Insular de Menorca, informe que no se llegó a realizar. Se entendió, pues, otorgado por la ficción legal del silencio administrativo positivo.

El otorgamiento de la licencia se concedió en virtud del Acuerdo de la Comisión de Gobierno del Ayuntamiento de Sant Lluís del día 3 de junio de 2004, es decir, más de seis meses después de que se hubiera solicitado el mencionado informe al Consell Insular de Menorca.

Contra dicho acuerdo se interpuso recurso contencioso-administrativo, que concluyó con la Sentencia núm. 64 de 2006 (JCA 1), de 2 de marzo de 2006. A su vez, se interpuso recurso de apelación, resuelto mediante la Sentencia núm. 214, de 6 de mayo de 2008 (TSJIB), en el Rollo núm. 106 de 2006. Dicha sentencia desestimó la apelación y confirmó la sentencia de instancia.

En ejecución de las referidas sentencias, el día 16 de enero de 2013, finalmente, se produjo la demolición de la vivienda y sus anexos, en una fecha en que ya se había iniciado la controversia sobre si era procedente o no la reclamación de responsabilidad patrimonial solicitada.

Así, lo que se trata de dilucidar ahora es el alcance de la indemnización y de si esta comprende los gastos realizados de buena fe y solamente estos o, además, deben incluirse también los de construcción y posterior demolición de las obras realizadas al amparo de la licencia declarada nula por los tribunales.

Para ello, el TSJIB se basa en la sentencia apelada y en la jurisprudencia de esta sala sobre la materia, que se recoge, entre otras, en la Sentencia de 9 de abril de 2007, por referencia a la de 20 de enero de 2005, según la cual la indemnización de daños y perjuicios por causas de anulación de licencias municipales (de obra, edificación, etc.) es consecuencia lógica de toda revocación de licencias por tal causa, tal como preveían el artículo 16 del Reglamento de Servicios y el artículo 172 de la anterior Ley, y recogían el artículo 232, párrafo 1, del texto legal vigente en el momento de producirse los hechos y el artículo 38 del Reglamento de Disciplina Urbanística (también vigente en ese momento), al proclamar el principio de responsabilidad de la Administración conforme al régimen jurídico general, por ser indudable que la anulación de una licencia ocasiona a su titular unos daños y perjuicios ciertos y determinables porque, en todo caso, supone la 
imposibilidad de continuar realizando la actividad autorizada e incluso puede llegarse a la demolición de lo realizado.

Por ello, es evidente que el administrado sufre en estos supuestos una lesión patrimonial que es consecuencia directa del obrar incorrecto de la Administración. De ello deriva la procedencia de la indemnización, que como regla nadie discute con base en la declaración de responsabilidad que los preceptos citados consagran en relación con el principio constitucional establecido en el artículo 106 de la Constitución — desde las sentencias del TC de 26 de febrero y 14 de marzo de 1980, de 26 de septiembre de 1981 y de 14 de diciembre de 1983, etc.- Como vemos, el TSJIB no parece optar por la aplicación de la doctrina de culpa compartida derivada de la actuación imprudente del reclamante al proseguir con unas obras litigiosas.

Efectivamente, el Tribunal opina que, en esta materia, la regla general tiene una importante excepción en la norma contenida en el número 2. ${ }^{\circ}$ del artículo 232 de la citada Ley (artículo 39 del Reglamento), que preceptúa que "en ningún caso habrá lugar a indemnización si existe dolo, culpa o negligencia graves imputables al perjudicado", prueba que ha de correr a cargo de quien la alegue - como causa de exoneraciónconforme a las reglas generales. Y, si bien es cierto que cuando se otorga una licencia que infringe el ordenamiento lo es a petición del interesado y como regla de conformidad con el proyecto presentado - lo que dificulta la posibilidad de alegar desconocimiento de la infracción (salvo en casos de ordenaciones urbanísticas incompletas o confusas, etc.)—, sin embargo, esto no es suficiente porque la nueva normativa no supone una exención total o absoluta de responsabilidad (frente al sistema anterior), sino que exige la existencia de dolo o culpa grave imputable al administrado. De idéntico modo se pronuncian otras sentencias como la dictada por la Sala el 26 de septiembre de 2000 (rec. cas. 3456/96 ), que expone que la responsabilidad por licencias urbanísticas se determina, según el artículo 232 del texto refundido de la Ley sobre Régimen del Suelo y Ordenación Urbana de 9 de abril de 1976, conforme a las normas que regulan con carácter general la responsabilidad patrimonial de la Administración; de ahí que para que sea viable una pretensión indemnizatoria de esta naturaleza se ha de haber producido un daño efectivo, evaluable económicamente, antijurídico e individualizable en relación con una persona o grupo de personas. 
Cuando concurren estas circunstancias, procede el derecho a indemnizar, siempre que no exista dolo, culpa o negligencia grave imputables al perjudicado — artículo 232 in fine del texto refundido de 1976 -

Tras entender que existe derecho a indemnización por los gastos ocasionados de buena fe, el TSJIB sostiene que, en consecuencia, el daño reclamado es indemnizable y que es responsable patrimonial de este el Ayuntamiento de Sant Lluís. Y a continuación fija el debate de la cuantía a satisfacer en los términos siguientes:

QUINTO.- En cuanto a la cuantía objeto de indemnización a partir de la consideración que se tiene que producir la reparación integral de los daños y perjuicios, tal y como afirmamos en nuestra [sentencia] núm. 828 de 27 de octubre de 2003 dictada en las actuaciones 126 de 2001, "La indemnización por anulación de la licencia atiende al principio de reparación íntegra y, en consecuencia, comprende todos los daños realmente producidos, esto es, los honorarios del proyecto y dirección de obras, las tasas municipales de expedición de la licencia, los gastos de declaración de obra nueva, los gastos de naturaleza financiera, las cesiones, los costes de la obra ejecutada y del material no utilizable, los gastos de demolición y el lucro cesante — sin que en éste quepa incluir las meras expectativas".

Estos y no otros, comprensivos del daño emergente y el lucro cesante, pues, serán los conceptos a tener en cuenta para resarcir al administrado. Indemnización que, hoy por hoy, no podemos cuantificar correctamente puesto que no hay hechos debidamente probados. No obstante, podrá, y así tendrá que hacerse, en trámite de ejecución de sentencia, tal como acordó también la sentencia de instancia apelada en la parte que estimó parcialmente el contencioso, cuando menos pero con la inclusión de los conceptos que decimos.

Todo esto, no obstante, con dos matizaciones, una primera, que el límite temporal para el abono de los gastos derivados de la licencia y las obras llevadas a cabo en principio lo marcaría la firmeza de la sentencia núm. 214 de 6 de mayo de 2008 dictada en el rollo núm. 106 de 2006; a partir de ella, pues, no habría derecho a percibir ningún gasto más de los efectuados; otra segunda, que como quiera que hemos dicho que también se tenían que incluir los gastos de demolición producida el mes de enero del año 2013 siempre, claro está y muy entendido, que si esta no hubiera ido en realidad a cargo de la Administración directamente, puesto que en este supuesto se tendrán que excluir expresamente.

Ahora bien, a pesar de lo que avanzamos, es importante tener en cuenta definitivamente como límite temporal más adecuado a estos efectos la fecha del 30 
de mayo de 2006 en que el Consorcio para la protección de la legalidad urbanística incoó el expediente administrativo núm. NUM002 con la pretensión de llevar a cabo la demolición de la vivienda en construcción después de conocer la sentencia de primera instancia de 2 de marzo de 2006, finalmente confirmada por la nuestra de 2008, acordándose, entre otras medidas, ordenar la suspensión inmediata de las obras tal y como se prevé, de forma tajante, en los artículos 61 y siguientes de la Ley 10/1990, de 23 de octubre, de disciplina urbanística de la CAIB. El día 27 de abril anterior se había levantado acta de la inspección de obras.

Fijación en ejecución que, en ningún caso, podrá superar el quantum interesado en la petita.

También habíamos señalado en la narración fáctica de la presente la existencia de un procedimiento bifásico, dadas las características descritas de la solicitud, que determinó la petición el mes de noviembre de 2003 de un informe vinculante al Consejo Insular de Menorca que no se produjo de forma expresa. Se entendió, pues, otorgado por la ficción legal del silencio administrativo positivo.

Este hecho, una vez finalizado el contencioso inicial de 2004 por la reiterada sentencia de 20 de mayo de 2008, determinó que el siguiente día 21 de octubre de 2008 el Sr. Indalecio presentara sendos escritos de reclamación de responsabilidad patrimonial solidaria en las sedes administrativas del Consejo Insular de Menorca y del Ayuntamiento de Sant Lluís - la derivación de la primera se está sustanciando hoy por hoy en el mencionado Juzgado Contencioso Administrativo núm. 1 de los de Palma.

En la primera instancia se adujo por la postulación del Ayuntamiento de Sant Lluís la excepción de litisconsorcio pasivo necesario. Excepción que no prosperó según los términos del $2 .^{\circ}$ de los fundamentos de derecho de la sentencia apelada. Se decía que:

"Únicamente cabe apreciar dicha excepción cuando la ley expresamente impone la obligación de dirigir la acción contra dos personas distintas y no es el caso de autos, por lo que el recurrente podía elegir contra quién dirigir la acción ejercitada".

Punto no cuestionado en la apelación presentada, tal vez debido a que el contencioso 29/2011 del referido Juzgado núm. 1 permanece ahora suspendido desde la provisión de 9 de noviembre de 2015 y donde se acordó:

"Dado que la sentencia que recayó en el Procedimiento Ordinario 175/2011 seguido en este juzgado puede tener efectos prejudiciales en la resolución que debe recaer en este proceso, se suspende el presente procedimiento en tanto no se resuelva el recurso de apelación que pende en la Sala presentado contra la mencionada sentencia". Suspensión decretada una vez cerrado el periodo probatorio del referido contencioso. 
En consecuencia, estimamos parcialmente la apelación instada por el Sr. Indalecio y desestimamos la apelación presentada por el Ayuntamiento de Sant Lluís dándose por reproducidos en cuanto a esta última los argumentos hasta ahora efectuados y que suponen el rechazo de la última de las citadas.

Así las cosas, la sentencia implica que el reclamante deberá ser indemnizado por todos los gastos ocasionados al disponer de una licencia urbanística de buena fe anulada en sede judicial. El Ayuntamiento de Sant Lluís deberá indemnizar todos los daños realmente producidos, esto es, los honorarios del proyecto y dirección de obras, las tasas municipales de expedición de la licencia, los gastos de declaración de obra nueva, los gastos de naturaleza financiera, las cesiones, los costes de la obra ejecutada y del material no utilizable, los gastos de demolición y el lucro cesante — sin que en este quepa incluir las meras expectativas-, aunque todo ello con los matices del fundamento de derecho transcrito (quinto), que puede implicar una reducción importante en la cuantía finalmente a satisfacer al atribuir cierto grado de responsabilidad al reclamante por los actos realizados tras la sentencia de anulación de la licencia y la orden de demolición.

Con todo, conceptualmente, la sentencia supone un giro importante respecto de la indemnización fijada por el Juzgado de lo contencioso.

3. Sobre la obligatoriedad de construir una pantalla acústica en una carretera: la Sentencia del Tribunal Superior de Justicia de las Islas Baleares (número 455/2016) de 14 de septiembre de 2016 (Id. Cendoj: 07040330012016100413, núm. procedimiento PO 059/2012 - Rollo de la Sala 129/2016)

En el tercer caso que planteamos se interpuso recurso contra la desestimación presunta, por efectos del silencio, del recurso de alzada presentado por el demandante ante la Presidencia del Consell Insular de Mallorca en fecha 10 de enero de 2012 contra la desestimación presunta de la solicitud presentada ante la Dirección General de Carreteras del Consell Insular de Mallorca el 16 de septiembre de 2011, en la que interesaba la construcción de una pantalla acústica para la protección de la parcela y vivienda de su propiedad, con unas dimensiones de 170 metros de longitud y 3,5 metros de altura.

El recurso ante el Juzgado de lo Contencioso-Administrativo núm. 2 de Palma obtuvo la Sentencia núm. 25/2016, de fecha 22 de enero, cuyo fallo decía literalmente: 
Que desestimo el recurso contencioso administrativo interpuesto por la Procuradora Dña. Magdalena Cuart Janer, en nombre y representación de D. Arcadio, contra la desestimación presunta por silencio administrativo del recurso de alzada presentado en fecha 10 de enero de 2012 contra la desestimación presunta de la solicitud presentada en fecha 16 de septiembre de 2011, sobre contaminación acústica.

Sin imposición de costas.

Contra la anterior sentencia se interpuso recurso de apelación en plazo y forma por la parte, que fue admitido en ambos efectos, siendo seguido el recurso con arreglo a los trámites de la Ley reguladora de la Jurisdicción Contencioso-Administrativa, señalándose para la votación y fallo el día 3 de junio de 2016. Por otro lado, mediante providencia de la misma fecha del señalamiento, con suspensión del plazo para dictar sentencia, la Sala sometió a las partes la cuestión relativa a la posibilidad de que existiese una estimación por doble silencio, habiéndose presentado alegaciones por los litigantes y señalándose de nuevo día para la votación y el fallo el día 9 de septiembre de 2016.

Debemos señalar que la sentencia apelada desestimó el recurso contenciosoadministrativo interpuesto. Igualmente, vemos que en el escrito de demanda el recurrente solicitaba que se anulase el acto presunto impugnado y que se condenara al Consell Insular de Mallorca (CIM), principalmente, a construir una pantalla acústica y, subsidiariamente, a pagar 65.656,76 euros, más el IVA correspondiente, así como a conceder licencia para las actuaciones destinadas a la subsanación de las deficiencias relativas a la contaminación acústica sufrida en su parcela.

El juzgador de instancia razona, en primer término, que la acción ejercitada por el actor no se incardina en un supuesto de responsabilidad patrimonial de la Administración, sino en la petición derivada del pretendido derecho subjetivo a solicitar el cumplimiento de los objetivos de calidad y emisiones acústicas, por lo que no resulta aplicable el plazo de prescripción de un año previsto en el artículo 142.5 de la Ley 30/1992, de 26 de noviembre, de Régimen Jurídico de las Administraciones Públicas y del Procedimiento Administrativo Común. A continuación, menciona la legislación estatal básica y la normativa autonómica aplicable en materia de ruido, y concluye que de la prueba practicada no se desprende que se superen los niveles de calidad acústica, al haberse efectuado únicamente una medición en período estival, cuando hay más tráfico, y en el exterior, a once metros de distancia de la vivienda, tratándose de una finca clasificada como suelo rústico, sin que el uso residencial se aprecie como el predominante. Para 
finalizar, el juzgador manifiesta que, frente al silencio mostrado por el Consell Insular, hubiese sido deseable que la Administración hubiese valorado objetivamente las circunstancias del tráfico en la zona para decidir si procedía llevar a cabo actuaciones para paliar los efectos del ruido.

A fin de resolver las cuestiones controvertidas — consistentes en dilucidar si el CIM, en cuanto titular de la autovía Ma-13, está obligado o no a adoptar medidas contra la contaminación acústica cuando estas son solicitadas por los supuestos perjudicados-, de la sentencia objeto de análisis se deben destacar los siguientes datos de hecho que resultan acreditados a partir del expediente administrativo, de las alegaciones y de las diligencias de prueba, respectivamente efectuadas y practicadas por los litigantes:

1) D. Arcadio, desde el 20 de septiembre de 2010, es propietario de un inmueble sito en la parcela NUM000 del polígono NUM001, del término municipal de Binissalem, sobre el que existe una edificación destinada a vivienda unifamiliar, estando clasificado por el Plan Territorial Insular de Mallorca como "suelo rústico general" (SRG), dentro de la unidad paisajística 8 (UP- 8), mientras que las Normas Subsidiarias de Planeamiento de Binissalem lo clasifican igualmente como suelo rústico común, con categoría de "área de interés agrario E”, con una franja paralela a la autovía clasificado como suelo rústico protegido (APT) y otra franja APT que discurre paralela al Camí des Pou d'en Torrents.

2) La finca originaria fue objeto de una expropiación forzosa para la ejecución de la autovía Ma-13, habiéndose alcanzado un acuerdo sobre el justiprecio entre la Administración expropiante y el anterior propietario el 17 de marzo de 1999. La autovía fue puesta en funcionamiento en los años 1994-1995.

3) La vivienda se encuentra entre 32,5 y 37 metros lineales de distancia de la autovía.

4) El 26 de enero de 2011, el abogado del actor presentó un escrito ante la Dirección General de Carreteras del Consell Insular de Mallorca, en el que denunciaba el nivel de inmisión acústica soportado en su vivienda a consecuencia de la autovía, interesando que se efectuasen mediciones y se ejecutasen las medidas correctoras pertinentes para eliminar y/o disminuir el ruido, mediante la instalación de pantallas contra el mismo. Se acompañaba una medición sonométrica, sin indicar el autor.

Esta petición fue reiterada en escritos presentados el 7 de abril de 2011 (también dirigido al Ayuntamiento de Binissalem) y el 16 de septiembre de 2011, al cual se adjuntó un informe de evaluación acústica realizado por la entidad "Centro de Estudio y Control de Ruido S.L.” (CECOR) durante 24 horas, solicitando la construcción de una pantalla acústica de 170 metros de largo por 3,5 metros de altura. 
El ensayo para calcular el nivel de inmisión de ruido ambiental se realizó el 30 de junio de 2011, durante 24 horas, desde un punto exterior de la vivienda, ofreciendo un resultado promedio de $68 \mathrm{dbA}$ durante el día, $67,1 \mathrm{dbA}$ por la tarde y $62,7 \mathrm{dbA}$ por la noche.

5) El 10 de enero de 2012 interpuso un recurso de alzada frente a la desestimación presunta de su reclamación, dirigido frente a la Presidencia del Consell Insular, el cual tampoco recibió respuesta.

Como se expresa en la Sentencia del TSJIB núm. 314/2014, de 29 de mayo, en la que se examinaba la conformidad a derecho del Acuerdo adoptado por el Pleno del Consell Insular de Mallorca de 2 de junio de 2011, que aprobó definitivamente el mapa estratégico de ruidos del eje Ponent-Llevant, carreteras Ma-1, Ma-19, tramo Palma-Llucmajor y Ma20:

El mandato constitucional de protección de la salud y del medio ambiente en sus artículos 43 y 45, y la regulación europea en materia de ruidos plasmada en la Directiva 2002/49/CE de 25 de junio han cristalizado en la Ley 37/2003 de 17 de noviembre reguladora de los Ruidos, todo ello con la finalidad de garantizar una buena calidad de vida a los ciudadanos y el disfrute de un medio ambiente saludable en la doble faceta de emisión de ruidos como de vibraciones.

Para ello las Administraciones vienen obligadas a prevenir, vigilar y reducir la contaminación acústica, para evitar y reducir los daños que de ésta pueden derivarse para la salud humana, los bienes o el medio ambiente (art. 1) y a tal efecto elaborarán aprobar y revisar los correspondientes mapas de ruido y la delimitación de zonas de servidumbre acústica (art. 4 a) y b)) ejecutar medidas previstas en el plan, (apartado f).

Respecto a la intervención de los entes públicos sobre los emisores acústicos —entre los cuales se incluyen las infraestructuras viarias por cuanto por ellas discurre el tráfico rodado-, el artículo 18 de la Ley estatal 37/2003, de 17 de noviembre, del Ruido (LR), de carácter básico, dispone que las administraciones públicas competentes aplicarán, en relación con la contaminación acústica producida o susceptible de producirse por los emisores acústicos, las previsiones contenidas en esta ley y en sus normas de desarrollo en cualesquiera actuaciones previstas en la normativa ambiental aplicable. Todo ello se despliega profusamente en diferentes textos legales y reglamentarios, y se concluye que en las áreas acústicas contaminadas las administraciones competentes deberán adoptar las medidas necesarias para la mejora acústica progresiva del medio ambiente hasta alcanzar 
el objetivo de calidad fijado mediante la aplicación de planes zonales específicos a los que se refiere el artículo 25.3 de la Ley 37/2003, de 17 de noviembre.

A partir de todo ello se demuestra que la evaluación de 24 horas para calcular el nivel de ruido ambiental aportada por la parte actora mostró una media de 68 dBA durante el día, 67,1 dBA por la tarde y 62,7 dBA por la noche, cuando los límites se encuentran en 55 dB por el día y $45 \mathrm{~dB}$ por la noche, de acuerdo con la tabla contenida en el artículo 6 del Decreto, con lo que se superaban en 13 y $12 \mathrm{~dB}$, respectivamente, los niveles máximos señalados durante el día (ampliables hasta $71 \mathrm{~dB}$ ) y en más de $15 \mathrm{~dB}$ los niveles máximos en horario nocturno (hasta $60 \mathrm{~dB}$ ). En todo caso, los resultados de las mediciones sonométricas realizadas a instancia del interesado ante la inactividad mostrada por el Consell Insular (al que se solicitó que las realizase en diversas ocasiones mediante escritos presentados el 26 de enero, el 7 de abril y el 17 de septiembre de 2011) indican la existencia de contaminación acústica. Sobre esta cuestión, el TSJIB critica el hecho de que el CIM había mostrado una total inactividad y pasividad al respecto.

De ello se desprende la obligación del CIM de construir la pantalla acústica. No obstante, el TSJIB abunda en la falta de resolución del recurso de alzada contra un acto presunto y manifiesta:

Por lo que concierne a los efectos del silencio administrativo respecto del recurso de alzada formulado, a su vez, contra una resolución presunta, el artículo 43.2 de la Ley 30/1992, de 26 de noviembre, de Régimen Jurídico de las Administraciones Públicas y del Procedimiento Administrativo Común (en adelante, LPAC, modificada por la Ley 4/1999, de 13 enero), dispone que: "Los interesados podrán entender estimadas por silencio administrativo sus solicitudes en todos los casos, salvo que una norma con rango de Ley o norma de Derecho Comunitario Europeo establezca lo contrario. Quedan exceptuados de esta previsión los procedimientos de ejercicio del derecho de petición, a que se refiere el art. 29 de la Constitución, aquellos cuya estimación tuviera como consecuencia que se transfirieran al solicitante o a terceros facultades relativas al dominio público o al servicio público, así como los procedimientos de impugnación de actos y disposiciones, en los que el silencio tendrá efecto desestimatorio.

No obstante, cuando el recurso de alzada se haya interpuesto contra la desestimación por silencio administrativo de una solicitud por el transcurso del plazo, se entenderá estimado el mismo si, llegado el plazo de resolución, el órgano administrativo competente no dictase resolución expresa sobre el mismo". 
Por su parte, el artículo 115.2 LPAC determina que "El plazo máximo para dictar y notificar la resolución será de tres meses. Transcurrido este plazo sin que recaiga resolución, se podrá entender desestimado el recurso, salvo en el supuesto previsto en el art. 43.2, segundo párrafo".

Como resulta del examen del expediente administrativo, el abogado del Sr. Arcadio presentó el 26 de enero, el 7 de abril y el 17 de septiembre de 2011 ante la Dirección General de Carreteras del Consell Insular de Mallorca una solicitud para que se efectuasen mediciones de los niveles sonoros soportados en su vivienda, así como para que se adoptasen las medidas correctoras oportunas, indicando la instalación de pantallas de protección acústica.

Desde la última reclamación de septiembre de 2011, transcurrido el plazo máximo supletorio de 6 meses previsto en el artículo 42.2 LPAC para dictar y notificar la solicitud, el solicitante interpuso recurso de alzada frente a la denegación por silencio de su petición, sin que tampoco recayese resolución expresa del mencionado recurso interpuesto frente al superior jerárquico.

Por consiguiente, ha de entenderse que la solicitud del recurrente había sido estimada por efecto del denominado "doble silencio", y en consecuencia la resolución expresa sólo podía tener sentido estimatorio de las pretensiones del actor, ya que la excepción al silencio positivo prevista en el artículo 43.2 LPAC no opera en el supuesto de la desestimación presunta del recurso de alzada formulada por el acto presunto, que por aplicación de la regla excepcional a los efectos positivos del silencio en los procedimientos iniciados a solicitud de los particulares, produce efectos negativos para el solicitante.

Las consideraciones anteriores obligan a la estimación del presente recurso de apelación y del recurso contencioso administrativo, por lo que el Consell Insular de Mallorca deberá construir una pantalla acústica para la protección de la parcela y vivienda propiedad del actor.

Por todo ello, el TSJIB resuelve:

$\left.1^{\circ}\right)$ ESTIMAR el recurso de apelación interpuesto por la representación procesal de D. Arcadio, contra la Sentencia dictada por el Juzgado $n^{\circ} 2$ de Palma, $n^{\circ} 25 / 2016$, de 22 de enero, la cual se revoca.

$\left.2^{\circ}\right)$ SE ESTIMA el recurso contencioso administrativo, por no ser conforme a derecho la resolución administrativa impugnada, anulándola.

$\left.3^{\circ}\right)$ SE RECONOCE EL DERECHO del actor a que el Consell Insular de Mallorca construya una pantalla acústica para la protección frente al ruido sufrido en la parcela y vivienda propiedad del actor. 
La resolución es interesante tanto desde el punto de vista ambiental del derecho a obtener una calidad acústica adecuada y protegida por la legislación del ruido como desde la perspectiva procedimental respecto a la cuestión del doble silencio.

\section{Sobre obras ilegales y órdenes de demolición: la Sentencia del Tribunal Superior de Justicia de las Islas Baleares (número 405/2016) de 6 de julio de 2016 (Id. Cendoj: 07040330012016100370, núm. procedimiento PO 013/2010 - Rollo de la Sala 178/2016)}

En el cuarto caso que planteamos se interpuso recurso contra las resoluciones recaídas en el expediente 2005/103 de la Comisión Insular de Ordenación del Territorio, Urbanismo y Patrimonio Histórico del Consell Insular de Mallorca, de fecha 27 de febrero de 2009, por las que se impusieron sanciones por la comisión de presuntas obras ilegales en el predio Biniatzent de Baix, en el municipio de Mancor de la Vall (Mallorca), a la vez que se acordaba la demolición de dichas obras, y contra la resolución expresa del recurso acordada por el Consejo Ejecutivo del CIM de fecha 2 de junio de 2010, que desestimaba el recurso de alzada interpuesto contra la resolución sancionadora.

La Sentencia núm. 77, de 17 de febrero de 2016, dictada por el Juzgado de lo Contencioso-Administrativo 2 de Palma, decía literalmente en su fallo:

Que estimo parcialmente el recurso contencioso administrativo interpuesto por el Procurador D. Juan José Pascual Fiol, en nombre y representación de D. Sebastián, contra las resoluciones recaídas en el expediente NUM000 de la Comisión Insular de Ordenación del Territorio, Urbanismo y Patrimonio Histórico del Consell Insular de Mallorca, de fecha 27 de febrero de 2009, por las que se le impuso una sanción por la comisión de presuntas obras ilegales en el predio DIRECCIONO00 (Mancor de la Vall) a la vez que se acordaba la demolición de dichas obras, y, contra la resolución expresa del recurso acordada por el Consell Executiu del CIM de fecha 2 de junio de 2010; y en consecuencia, se reduce el importe de la sanción impuesta a la suma total de $171.333,68$ euros.

Que estimo el recurso contencioso administrativo interpuesto por el Procurador D. Juan José Pascual Fiol, en nombre y representación de D. Calixto, contra las resoluciones recaídas en el expediente NUM000 de la Comisión Insular de Ordenación del Territorio, Urbanismo y Patrimonio Histórico del Consell Insular de Mallorca, de fecha 27 de febrero de 2009, por las que se le impuso una sanción por 
la comisión de presuntas obras ilegales en el predio DIRECCION000 (Mancor de la Vall) a la vez que se acordaba la demolición de dichas obras, y, contra la resolución expresa del recurso acordada por el Consell Executiu del Consell Insular de Mallorca (CIM) de fecha 2 de junio de 2010; y en consecuencia, dejo sin efecto la sanción que le fue impuesta.

Declaro la inadmisibilidad parcial del contencioso interpuesto por D. Sebastián, en cuando a la orden de demolición, por haber devenido firme.

Se mantienen el resto de pronunciamientos contenidos en las resoluciones impugnadas.

Sin expresa imposición de costas.

Contra la anterior resolución se interpuso recurso de apelación en plazo y forma por la parte demandada, el Consell Insular de Mallorca (CIM), del que se dio traslado a la parte demandante, que se opuso a la apelación y a la vez se adhirió a la apelación que fue admitida en ambos efectos, sin que ninguna de las partes propusiese la práctica de prueba, siendo seguido el recurso con arreglo a los trámites de la Ley reguladora de la Jurisdicción Contencioso-Administrativa, tras lo cual los autos quedaron conclusos para dictar sentencia y se señaló para la votación y fallo el día 5 de julio de 2016.

Como antecedentes fácticos relevantes interesa recordar:

Que como consecuencia de procedimiento sancionador y de disciplina urbanística con motivo de unas obras ejecutadas sin licencia en una zona de suelo rústico con categoría de área natural de especial interés (ANEI), el Consell Insular de Mallorca, a través de su Comisión Insular de Ordenación del Territorio, Urbanismo y Patrimonio Histórico, en subrogación del Ayuntamiento y por inactividad de este, dictó dos resoluciones de fecha 27 de febrero de 2009 por las que se impusieron sanciones por la comisión de presuntas obras ilegales y se acordó la demolición de dichas obras.

Que en fecha 2 de abril de 2009 el Sr. Sebastián interpuso recurso de alzada contra la resolución sancionadora de fecha 27 de febrero de 2009, interesando que se declarase la nulidad del expediente sancionador y, subsidiariamente, que se revisara de oficio y anulara la resolución sancionadora para que se suspendiera el procedimiento en tanto no finalizara la legalización de las obras.

Subsidiariamente a todo lo anterior, se solicitaba que la cuantía de la sanción fuese de 9.224,93 euros, es decir, el 5\% de la valoración de la obra ejecutada, o, subsidiariamente, en la cuantía de 12.494,70 euros (al añadirse otros gastos) o como máximo 92.249,25 
euros (que es lo que el demandante entiende que debería ser la cuantía de la sanción máxima aplicable).

Que mediante Resolución del Consejo Ejecutivo del CIM de fecha 2 de junio de 2010 se desestimó el recurso de alzada interpuesto contra la resolución sancionadora.

Frente a la anterior se interpuso recurso contencioso-administrativo que indicaba que esta desestimaba el recurso de alzada interpuesto contra las dos resoluciones de fecha 27 de febrero de 2009, esto es, la resolución que impone sanción y la resolución que acuerda la demolición de las obras.

La sentencia aquí apelada, al margen de exculpar a otro sancionado por motivos que no afectan a la apelación, señala:

$1^{\circ}$ ) Inadmisible el recurso contencioso-administrativo interpuesto contra la orden de demolición de fecha 27.02.2009 al no haber sido recurrida en tiempo y forma. Se considera que el recurso de alzada interpuesto en fecha 2 de abril de 2009 lo era exclusivamente contra la resolución sancionadora de la misma fecha, pero no contra la resolución acordando la demolición.

$2^{\circ}$ ) Que procedía estimar parcialmente el recurso interpuesto contra la sanción, rebajando el importe de la multa al $50 \%$ en aplicación de lo dispuesto en el art. 45 y 46 de la entonces vigente Ley 10/1990, de Disciplina Urbanística de la CAIB.

El Consell Insular de Mallorca interpone recurso de apelación contra el pronunciamiento por el que se acuerda rebajar el importe de la multa al 50\% del valor de las obras ejecutadas ilegalmente. Se solicita que se mantengan las multas en la cuantía fijada por la Administración. Concretamente, se argumenta que, una vez que resulta admitido que el hecho infractor consiste en la ejecución de obras sin licencia y que estas obras se realizaron sobre espacios protegidos (ANEI concretamente), no son de aplicación los artículos 45 y 46 citados en la sentencia apelada - referidos a ejecución de obras sin licencia en espacios no especialmente protegidos-, sino que es de aplicación el artículo 47, que expresamente prevé que en tales supuestos de obras en suelos o edificaciones protegidos la sanción de multa será del 100\% al 200\% del valor de las obras.

A su vez, la representación del particular se opone al recurso de apelación y, además, formula adhesión a la apelación e interesa que la sentencia se revoque en cuanto al tercer pronunciamiento (declaración de inadmisibilidad parcial del contencioso en cuanto a la orden de demolición) para que en su lugar se declare admisible y, ya en cuanto al fondo, 
que se anule la orden de demolición porque esta no puede acordarse sin previo pronunciamiento sobre la ya solicitada legalización de las obras.

La infracción cometida consiste en la ejecución de obras sin licencia urbanística (art. 27.1.b de la LDU 10/1990). La infracción se clasificó como grave al afectar a bienes e intereses protegidos. No se discute la comisión de la infracción, como tampoco se discute que esta se cometió en un área natural de especial interés (ANEI). Esto último es relevante a los efectos de la imposición de la cuantía de la sanción a establecer: se reconoce que se realizaron obras en suelo rústico de protección especial y valor ambiental.

La resolución administrativa sancionadora desglosó las obras infractoras en dos bloques: a) obras de construcción de una balsa y b) resto de obras.

Para las primeras se estimó que, de conformidad con el artículo 47 de la Ley 10/1990, eran sancionables con multa del $100 \%$ al $200 \%$ del valor de las obras, y, como no concurrían ni circunstancias agravantes ni circunstancias atenuantes, se impuso sanción en el medio de la franja, esto es, del $150 \%$ del valor de las obras.

Para las segundas se estimó que, también de conformidad con el artículo 47 de la Ley 10/1990, eran sancionables con multa del 100\% al 200\% del valor de las obras, y, como aquí sí concurría una agravante (concretamente la del artículo 34.1 de LDU por no haber acatado la orden de suspensión de las obras), procedía imposición de multa del 200\% de su valor.

Sin embargo, la sentencia apelada reduce el importe de las dos sanciones al 50\% del valor de las obras. Los argumentos del Juzgado implican que, de seguirse su criterio, tendría la misma consideración la ejecución de obras sin licencia en suelo especialmente protegido que las ejecutadas en suelo sin dicha consideración, cuando el artículo 38 y el análisis comparativo entre los artículos 45 y 47 ya evidencian que no es así. Pero no solo esto, sino que la sentencia, tras apreciar - erróneamente - que la franja sancionadora era la del artículo 45 (del 50\% al 100\% del valor de las obras), aprecia que debe imponerse el mínimo de la franja (el 50\%). Tampoco es acertado el criterio de imponer la sanción mínima, pues el artículo 34 ya regula los criterios de graduación de la sanción, conforme a los cuales, si concurre alguna circunstancia agravante, la sanción se impone en el grado máximo (art. 34.1); si concurre alguna circunstancia atenuante, la sanción se impone en el grado mínimo (art. $34.2^{\circ}$ ); por lo que, finalmente, si no concurren circunstancias atenuantes o agravantes, por exclusión debe imponerse en grado medio. 
En cambio, los argumentos de la Sala para resolver esta cuestión son:

En cualquier caso, y aunque la extemporánea invocación de un motivo de impugnación que debió realizarse en la instancia ya obliga a su rechazo, sin embargo debemos precisar que rectificamos la doctrina contenida en aquella sentencia (la otra mencionada, la núm. 381/2015 de 3 de junio, parte de supuesto distinto) por cuanto el juego del art. 34 LDU conduce al esquema siguiente: $1^{\circ}$ ) si concurre alguna circunstancia agravante, la sanción se impone en el grado máximo (párrafo $1^{\circ}$ ); $2^{\circ}$ ) si concurre alguna circunstancia atenuante, la sanción se impone en su grado mínimo (párrafo $\left.2^{\circ}\right) ; 3^{\circ}$ ) en consecuencia, si no hay ni agravantes ni atenuantes, debe imponerse en su grado medio ya que de lo contrario si se impone en su grado mínimo la sanción por infracción sin circunstancias modificativas, se equiparan incorrectamente a los casos en que concurren atenuantes.

La representación del Sr. Sebastián en la oposición al recurso de apelación invoca que la sanción agravada del art. 47 no es de aplicación a supuestos de obras que, como el caso, son legalizables aunque no se solicite la legalización en plazo (supuesto f del art. 45).

No es así, en los supuestos del art. 47, la única reducción posible a la sanción inicialmente prevista (del 100 al 200\%) es la reducida del $5 \%$ cuando las obras puedan ser objeto de legalización y que dicha legalización se haya solicitado en plazo y no se haya desobedecido la orden de paralización. Ello se desprende de que el párrafo $2^{\circ}$ del art. 47 excluya la reducción al $5 \%$ en los supuestos de los apartados f) y g) del art. 45. Concretamente, el segundo párrafo del art. 47 prevé que "si estas obras o instalaciones pueden ser objeto de legalización, la sanción será del $5 \%$ del valor de las obras realizadas o del terreno, según corresponda, excepto en los casos previstos en los epígrafes f) y g) del art. 45 de esta Ley.

En el caso, no se pararon las obras pese al requerimiento de la administración (en cuanto al grupo de "otras obras") ni se solicitó la legalización en plazo (en cuanto a las obras de la balsa), por lo que no podía aplicarse la reducción al $5 \%$, única reducción posible en obras graves como la del caso, esto es, las ejecutadas sobre espacios protegidos.

Por ello, deviene irrelevante toda la argumentación expresada por la representación del Sr. Sebastián con respecto a las vicisitudes en las gestiones tendentes a la legalización de las obras. A efectos de la sanción, no interfieren porque, repetimos, sólo incidirían para una posible reducción al $5 \%$ en el caso de que no operasen las excepciones (orden de paralización desobedecida o solicitud de legalización en 
plazo), pero aquí operan. La propia parte apelante reconoce que instó la legalización fuera del plazo concedido (párrafo $2^{\circ}$ de la pág. 6 del escrito de apelación).

Una vez que no cabe la aplicación de la sanción reducida al $5 \%$ y que por tanto se ha imponer en la franja del 100 al $200 \%$, la graduación depende de las agravantes y atenuantes. Pues bien, la sentencia - aunque sea sobre la errónea sanción del art. 45- determina que se imponga en el grado medio (50\%) pero sin explicar porqué. No se sabe si es porque se aprecia que no hay ni agravantes ni atenuantes o porque concurren las dos, de modo que se compensan.

La imposición de la sanción en el grado medio en la sanción referida a la balsa, no ofrece discusión porque es la que ha aplicado la propia administración.

La imposición de la sanción en el grado máximo en la sanción referida a las "otras obras" está justificada en la resolución sancionadora por la concurrencia de una agravante, concretamente la del art. 34.1 de LDU por no haber acatado la orden de suspensión de las obras. La sentencia apelada reconoce la procedencia de esta agravante y no nos indica qué supuesta atenuante concurriría, por lo que no había otra posibilidad que mantener la multa en el grado máximo. La representación del Sr. Sebastián supone que el Juzgado atendió a la concurrencia de las atenuantes "invocadas en la demanda", pero ni en la demanda ni en la apelación encontramos la cita y aplicación al caso de algunas de las del art. $34,2^{\circ}$ y $3^{\circ}$ LDU. En cualquier caso, ni el culpable realizó actuaciones para minimizar el daño antes del inicio de las actuaciones inspectoras; ni se puede invocar desconocimiento técnico ante una infracción tan básica y elemental (la necesidad de recabar licencia antes de ejecutar obras); tampoco afecta el beneficio económico que se derive de la infracción. En definitiva, no concurre ninguna atenuante.

Procede por tanto la estimación del recurso de apelación del Consell Insular de Mallorca.

Por todo ello, el TSJIB decide estimar el recurso de apelación interpuesto por la representación procesal del Consell Insular de Mallorca y fija la sanción en los términos fijados en los razonamientos de derecho arriba transcritos, en atención a la gravedad de las infracciones cometidas en un área natural de especial interés (ANEI). 
5. Sobre imputación de gastos por ejecución subsidiaria: la Sentencia del Tribunal Superior de Justicia de las Islas Baleares (número 422/2016) de 12 de julio de 2016 (Id. Cendoj: 07040330012016100358, núm. procedimiento PO 179/2012 - Rollo de la Sala 203/2016)

La quinta sentencia seleccionada se refiere al recurso interpuesto contra la Resolución de 8 de junio de 2012, del conseller ejecutivo de Urbanismo y Territorio del Consell Insular de Mallorca y presidente de la Agencia de Disciplina Urbanística, por la que se desestimó el recurso de alzada formulado contra la Resolución de 13 de febrero de 2012, del director gerente de la Agencia de Disciplina Urbanística del Consell Insular de Mallorca, por la que se liquidaban al recurrente los gastos de la ejecución subsidiaria del derribo de una vivienda unifamiliar aislada e ilegalizable, en el término municipal de Campanet (Mallorca).

El recurrente, como consecuencia de la ejecución de una serie de obras clandestinas en suelo rústico protegido, resultó obligado en 2004 a llevar a cabo la demolición correspondiente y la restauración de los terrenos a su estado natural. Esta obligación se origina en una orden de ejecución que concedía un plazo de tres meses y quince días para materializarla. Sin embargo, el recurrente no cumplió con su obligación ni en el plazo señalado ni en ningún momento. Ese incumplimiento se debía traducir en que el Consell Insular de Mallorca se encargase de la ejecución de la demolición con cargo al infractor. Para ello, hubo que esperar, como ya hemos dicho, siete años, es decir, hasta 2011. Durante esos siete años el infractor recurrente estuvo obligado a cumplir una orden que seguía vigente.

Es evidente que ante tal dilación en materializar una obligación (entre 2004 y 2011), una vez que en 2011 fue iniciada la tramitación de la ejecución subsidiaria ya no estaba permitido el cumplimiento tardío del recurrente, sino que lo que le tocaba entonces era hacerse cargo del coste de esa ejecución subsidiaria, tal y como prevé la legislación en materia de disciplina urbanística.

A la vista del resultado de sus acciones de incumplimiento, el recurrente intenta una táctica desesperada discrepando de la cantidad girada por la demolición en fase de ejecución subsidiaria y discrepando de aspectos procedimentales.

Sobre este punto, el Tribunal respeta la posibilidad de discrepar respecto al coste de ejecución, pero le recuerda al recurrente que tuvo siete años para realizar por sus propios 
medios la demolición asociada al expediente de disciplina urbanística y no lo hizo. Por ello, el hecho de que el coste haya superado las previsiones iniciales no tiene ninguna relevancia dado que lo que importa es que la cantidad girada por tal concepto esté debidamente justificada.

En cuanto a la discrepancia procedimental y a la metodología seguida para contratar la ejecución subsidiaria por parte de la Administración, nos sitúa ante una controversia inadmisible como consecuencia de la misma infracción y orden de ejecución subsidiaria. Pues bien, sobre esa discrepancia la sentencia apelada desestimó el recurso, pero como novedad en la apelación el recurrente esgrime, en primer lugar, que merecía una liquidación provisional que no se dio, máxime a la vista de la diferencia entre el contrato adjudicado y la liquidación girada. En este sentido, hay que señalar que, como se le indica al apelante, la práctica de una liquidación provisional no es una obligación que la Ley imponga a la Administración actuante, sino que esta puede o no realizarla, sin que realizarla o no dependa de la cuantía del contrato adjudicado — artículo 98.4 de la Ley $30 / 1992-$.

Según afirma el Tribunal:

Como una manifestación de su desorientación, el Sr. Sebastián alude también a que la Administración habría sacrificado en el caso los derechos que se le reconocen en el artículo 35.e) de la Ley 30/1992. Pero el Sr. Sebastián no concreta más y resulta que ese precepto se refiere a la posibilidad del afectado de presentar alegaciones o documentos en todo momento del procedimiento, lo que no consta que se le hubiera impedido en el caso. Otra cosa es que el Sr. Sebastián acaso confunda ese derecho que la Ley le brinda con una supuesta obligación de la Administración actuante de abrir un trámite de audiencia previa a la liquidación. Lo cierto es que, iniciado el expediente, la Administración otorgó un trámite de audiencia, pero no está previsto por la Ley un trámite de audiencia previa a la liquidación. Por lo tanto, ese trámite no se le abrió al Sr. Sebastián.

También se cuestiona que el recurso de alzada presentado por el apelante fuera informado por quien había suscrito la liquidación, invocándose al respecto el artículo 13.2.c) de la Ley 30/1992. Pero esa norma impide que el recurso de alzada se resuelva por delegación, lo que no es el caso, ni puede confundirse con el caso que sí que se da, que es el de que la notificación de la liquidación la suscriba el secretario de la Agencia por delegación del 
secretario general del Consell y el informe al recurso de alzada lo suscriba el director gerente.

Dicho lo anterior, hay que señalar también que las dudas que abriga el recurrente no tienen razón de ser. Sin que en el caso lo sea, era perfectamente posible jurídicamente que la resolución del recurso de alzada se basase por entero en el informe del director gerente, y ello porque lo que la ley protege en el artículo 13.2.c) de la Ley 30/1992 no es sino la separación entre el órgano que dicta la resolución originaria y el órgano que dicta la resolución del recurso de alzada, siendo lógico que el recurso de alzada se informe por quien dictó la resolución recurrida.

Por todo ello, el Tribunal acaba argumentando lo siguiente:

Puestas así las cosas, y siendo pacífico que el coste de la ejecución corresponde al Sr. Sebastián —artículos 96.1.b ) y 98 de la Ley 30/1992 y artículos 66.1 y 68 de la Ley CAIB 10/1999 - , no cabe aceptarle al Sr. Sebastián la legitimación para la defensa de los hipotéticos derechos de los competidores con la entidad adjudicataria del contrato del caso, lo que es debido a lo que ya es bien sabido, esto es, que el Sr. Sebastián no era partícipe en esa convocatoria.

Ocurre también en el caso que la fórmula contractual operada fue la recogida en modelo destinado con habitualidad a los contratos de ejecución de obras, donde los costes de eliminación y tratamiento de residuos son, puede decirse llanamente, lo de menos, mientras que en los contratos como el del caso, correspondiente a obra de restauración de los terrenos a su estado natural, lo que incluye, como es lógico, las demoliciones correspondientes, dichos costes son importantísimos.

Por consiguiente, es natural que el contratista corra con esos gastos en el contrato de obras de construcción y no en el contrato de obras de restauración de los terrenos a su estado natural, que es lo que en el caso ha pasado, donde ni siquiera figuran en la oferta a la que el contrato se adjudicó. Lo mismo ocurre con los gastos de descontaminación y retirada y tratamiento de los residuos de demolición y construcción.

Por último, en cuanto a qué es lo que debía demolerse, sobre lo que el recurrente muestra su disconformidad con lo ocurrido, nos cabe decir que la discrepancia se asienta en la idea equivocada de que la demolición no alcanzase, es decir, no comprendiera todas las actuaciones que son precisas para la reposición de los terrenos a su estado natural, alterado por las obras clandestinas que el infractor realizó en su día. 
6. Sobre restitución de la legalidad urbanística y de la realidad física alterada: la Sentencia del Tribunal Superior de Justicia de las Islas Baleares (número 439/2016) de 26 de julio de 2016 (Id. Cendoj: 07040330012016100383, núm. procedimiento PO 187/2012 - Rollo de la Sala 061/2016)

El sexto y último caso que planteamos consiste en la interposición de recurso contra la resolución dictada por la alcaldía del Ayuntamiento de Sant Joan de Labritja (Ibiza) el 23 de julio de 2012, que resolvía y desestimaba el recurso de reposición interpuesto contra resolución de expediente sancionador y de reposición de la legalidad urbanística contra la entidad AIBS DOS CORTIJO DOS, S. L. Tal recurso fue luego ampliado a la orden de demolición inmediata de las obras realizadas en virtud del Decreto de Alcaldía de 25 de mayo de 2012, que concedía a la propiedad un plazo de un mes para ejecutar por ella misma la referida demolición.

El Juzgado Contencioso-Administrativo núm. 1 de Palma de Mallorca dictó la interlocutoria núm. 291, de 22 de septiembre de 2015, donde desestimó la pretensión articulada por la parte actora de suspender la resolución administrativa impugnada, en sede de medidas cautelares. Ante tal denegación de suspensión, se interpuso recurso de apelación por parte de la representación de la parte actora, en el plazo prefijado en la Ley Jurisdiccional de 1998, y se le dio el trámite procesal adecuado, al cual se opusieron las direcciones letradas de las partes demandada y codemandada. Finalmente, por provisión del TSJIB se señaló, para la votación y decisión, el día 26 de julio de 2016, y la Sala acepta en parte los razonamientos jurídicos que emplea la interlocutoria de instancia y en su totalidad la decisión a la cual llega.

La cuestión central radica en la adopción o no de medidas cautelares ante órdenes de demolición, dado que la revisión jurisdiccional trataba sobre la resolución dictada por la alcaldía del Ayuntamiento de Sant Joan de Labritja (Ibiza) el 23 de julio de 2012, que resolvía y desestimaba el recurso de reposición interpuesto contra resolución de expediente sancionador y de reposición de la legalidad urbanística contra la entidad AIBS DOS CORTIJO DOS, S. L. Dicho recurso fue ampliado posteriormente a la Orden de 28 de abril de 2015 que imponía la demolición inmediata de las obras realizadas en virtud del Decreto de Alcaldía de 25 de mayo de 2012, que concedía a la propiedad un plazo de un mes para ejecutar por ella misma la mencionada demolición. Aquí, no obstante, nos movemos en el seno de una pieza separada de suspensión en la que la entidad actora, mediante escrito separado del recurso contencioso-administrativo inicial, interesó, 
precisamente, la suspensión de los efectos del decreto recurrido y de todos aquellos que se pudieran dictar en su ejecución, en especial el del día 28 de abril de 2015.

Dicho esto, sin embargo, hay que dar respuesta al que es, en definitiva, el motivo de la controversia, es decir, si es o no susceptible de adoptarse la medida cautelar interesada. Tal como nos recuerda la interlocutoria de la Sección 7. a de la Sala Tercera del Tribunal Supremo de 23 de noviembre de 2004, la jurisprudencia ha delimitado la naturaleza y el alcance de las medidas cautelares. La doctrina del Supremo afirma que "la jurisprudencia del Tribunal Constitucional (en STC 22/84, 66/84, 238/92, 148/93, y la de 13 de octubre de 1998, al resolver el recurso de amparo $n^{\circ}$ 486/97) ha reconocido el principio de autotutela administrativa, que no es incompatible con el artículo 24.1 de la CE, engarza con el principio de eficacia previsto en el artículo 103.1 de la CE y se satisface facilitando que la ejecución se someta a la decisión de un Tribunal y éste resuelva sobre la suspensión". Igualmente, se sostiene en sede constitucional que "[e]n reiterada doctrina de esta Sala, en torno al principio de eficacia de la actividad administrativa (artículo 103.1 de la Constitución), y al de la presunción de validez de los actos administrativos (artículo 57 de la Ley 30/92, de 26 de noviembre, precepto que no ha sido modificado por la Ley 4/99), la regla general es la ejecutividad inmediata de los actos y disposiciones y la posibilidad de suspensión se produce cuando se originen perjuicios de reparación imposible o difícil". Por otro lado, la aplicación del principio de efectividad de la tutela judicial (artículo 24.1 de la Constitución) “impone el control jurisdiccional sobre la actividad administrativa (artículo 106.1 de la Constitución) y, en todo caso, han de coordinarse y armonizarse la evitación del daño a los intereses públicos que pueda derivarse de la suspensión de la ejecución y que al ejecutarse el acto se causen perjuicios de imposible o difícil reparación para el recurrente, lo que implica un juicio de ponderación, como ha señalado este Tribunal (en Autos de 15 de enero, 21 de febrero, 28 de febrero, 14 y 18 de marzo, 8 de abril, 18 de julio y 8 de noviembre de 1994, 1 de abril, 22 de mayo, 19 de septiembre y 13 de diciembre de 1995, 20 de julio y 7 de noviembre de 1996 y 16 de septiembre de 1997)".

Por otro lado, el TSJIB ha sentado la jurisprudencia siguiente en algunas sentencias (como la número 249, de 19 de marzo de 2013):

También hemos de señalar que en la valoración de la medida cautelar solicitada es preciso en primer lugar que la parte aporte una cumplida prueba de la acreditación del perjuicio grave e irreparable ya que la mera enunciación de ese perjuicio no 
supone tal acreditación. No en vano y del artículo 129 de la Ley de la Jurisdicción Contencioso-Administrativa se desprende, la medida cautelar es la excepción a la indiscutible ejecutabilidad del acto administrativo dimanante de la presunción de legalidad y acierto de que goza. Por lo tanto es carga probatoria del solicitante ese extremo.

En segundo lugar el conocimiento de la pieza separada de la medida cautelar supone un conocimiento limitado de la cuestión ya que es imposible el análisis de fondo o sustantivo debiendo limitarse únicamente al examen de los perjuicios que la ejecutabilidad del acto depara al recurrente. Ello no excluye que como criterio a valorar para la posibilidad de la concesión de la medida, se examine la apariencia de buen derecho que ostenta el recurrente. Aunque siempre con el limitado carácter que la pieza separada de medida cautelar exige y sin poder prejuzgar el fondo del asunto. En tercer lugar es fundamental el criterio del periculum in mora, esto es, el aseguramiento del proceso que pasa por la valoración de que la ejecutabilidad del acto pueda producir una situación que convierta en inviable el recurso contencioso, haciéndole perder su finalidad, aun en el caso de que viera prosperar la tesis el demandante.

Igualmente, en la Sentencia núm. 126, de 5 de marzo de 2014, se sostuvo lo siguiente:

Por último debe ponderarse la intensidad que el interés general demanda de la ejecución inmediata del acto; así como reitera hasta la saciedad la jurisprudencia “cuando las exigencias de ejecución que el interés público presenta son tenues bastarán perjuicios de escasa entidad para provocar la suspensión; por el contrario, cuando aquella exigencia es de gran intensidad, sólo perjuicios de elevada consideración podrán determinar la suspensión de la ejecución del acto.

Pues bien, dadas las anteriores consideraciones, el Tribunal se encontraba ya en condiciones de dar respuesta a la controversia. Por una parte, nos encontramos ante una cuestión relativa a la disciplina urbanística donde, aparentemente - aspecto que se dilucidará en el fondo del litigio- - se ha producido una perturbación y vulneración de la legalidad urbanística. Por otra, lo que analiza la sentencia aquí tratada es si procede o no adoptar medidas de suspensión del acto de ejecución de una demolición de obras presuntamente ilegales.

El Tribunal afirma que ante un caso de estas características hay que extremar, más que nunca, las cautelas. Sin embargo, la sentencia sostiene que aquí la presunción es en favor de la Administración, que ha decidido adoptar una resolución después de la tramitación 
del oportuno expediente con intervención y contradicción de las partes y órdenes específicas de derribo. Esta orden específica ya se visualizaba en la resolución administrativa de 25 de mayo de 2012 y sobre la cual el Juzgado de instancia basaba su hilo argumental para desestimar la medida cautelar interesada.

Las cautelas tienen que ser, preventivamente, de mayor entidad, porque de otorgarse la medida cautelar de suspensión con los efectos pretendidos, es decir, el mantenimiento de aquello indebidamente efectuado, y después se considerara por los tribunales, al ratificar los actos administrativos, que las obras no venían amparadas legalmente, los perjuicios para el interés público serían más graves. La Administración está obligada a verificar el control administrativo y si el daño es reparable económicamente, prevalece el interés general.

Por otro lado, a juicio del Tribunal, aquí y ahora no hay apariencia de buen derecho, todo lo contrario. Y, además, la recurrente tampoco ha sido capaz de acreditar, ni tan solo de forma indiciaria, los perjuicios reales que se le ocasionan con el mantenimiento de la situación anterior al dictado de las resoluciones administrativas recurridas, especialmente dados los plazos transcurridos.

Toda esta argumentación conduce al TSJIB a desestimar el recurso de apelación y a confirmar la doctrina en materia de medidas cautelares en controversias relativas a la disciplina urbanística. 
Sumari: 1. Sobre la responsabilitat patrimonial derivada de modificacions de la normativa urbanística en sòls urbanitzables: la Sentència del Tribunal Superior de Justícia de les Illes Balears (número 401/2016), de 5 de juliol de 2016 (ID. Cendoj: 07040330012016100349, núm. procediment PO 190/2012 - Rotlle de la Sala 123/2016). 2. Sobre responsabilitat patrimonial derivada d'una anul·lació judicial de llicència d'obres: la Sentència del Tribunal Superior de Justícia de les Illes Balears (número 412/2016), de 7 de juliol de 2016 (ID. Cendoj: 07040330012016100376, núm. procediment PO 175/2011 - Rotlle de la Sala 381/2015). 3. Sobre l'obligatorietat de construir una pantalla acústica en una carretera: la Sentència del Tribunal Superior de Justícia de les Illes Balears (número 455/2016), de 14 de setembre de 2016 (ID. Cendoj: 07040330012016100413, núm. procediment PO 059/2012 - Rotlle de la Sala 129/2016). 4. Sobre obres il-legals i ordres de demolició: la Sentència del Tribunal Superior de Justícia de les Illes Balears (número 405/2016), de 6 de juliol de 2016 (ID. Cendoj: 07040330012016100370, núm. procediment PO 013/2010 - Rotlle de la Sala 178/2016). 5. Sobre imputació de despeses per execució subsidiària: la Sentència del Tribunal Superior de Justícia de les Illes Balears (número 422/2016), de 12 de juliol de 2016 (ID. Cendoj: 07040330012016100358, núm. procediment PO 179/2012 - Rotlle de la Sala 203/2016). 6. Sobre restitució de la legalitat urbanística i de la realitat física alterada: la Sentència del Tribunal Superior de Justícia de les Illes Balears (número 439/2016), de 26 de juliol de 2016 (ID. Cendoj: 07040330012016100383, núm. procediment PO 187/2012 - Rotlle de la Sala 061/2016).

Examinades les sentències en el camp del dret ambiental del segon semestre del 2016, veiem que no s'han generat resolucions amb un excessiu interès especial. En aquest número hem destacat sis resolucions que, tret d'una relativa a contaminació acústica i una altra a la protecció d'espais naturals d'especial protecció, se centren bàsicament en temes de disciplina urbanística i de responsabilitat patrimonial per l'adopció de mesures de protecció territorial.

D'una banda, pot tenir especial interès la Sentència del Tribunal Superior de Justícia de les Illes Balears (número 455/2016), de 14 de setembre de 2016, relativa a l'obligatorietat o no de mitigar els efectes de la contaminació sonora pel fet de construir una infraestructura viària de nou encuny que provoca emissions $\mathrm{i}$ immissions superiors a les que preveu la legislació relativa a la protecció enfront del soroll. La pregunta plantejada és si en sòl rústic també sorgeix aquest deure de mitigar la contaminació sonora i fins a quin punt l'Administració que va construir la carretera ha de resoldre el problema.

Igualment, i d'altra banda, la denegació del dret de rebre una indemnització per responsabilitat patrimonial es manifesta en dues sentències de sentit contraposat, una derivada de la correcta aplicació normativa de protecció territorial, en una successiva sèrie d'instruments de més protecció, i una altra derivada d'una deficient actuació municipal amb l'atorgament d'una llicència que va ser anul·lada perquè no s'ajustava a dret.

Les altres sentències tracten temes de control de la legalitat urbanística: una, sobre el marge i el límit que condicionen l'adopció o no de mesures cautelars davant de casos d'ordres de demolició com a conseqüència d'aquest control disciplinari; i les altres dos, 
sobre la mateixa matèria: ordres de demolició i execució subsidiària per part de l'Administració que corren diferent sort.

A continuació, analitzarem les sentències seleccionades.

\section{Sobre la responsabilitat patrimonial derivada de modificacions de la normativa urbanística en sòls urbanitzables: la Sentència del Tribunal Superior de Justícia de les Illes Balears (número 401/2016), de 5 de juliol de 2016 (ID. Cendoj: 07040330012016100349, núm. procediment PO 190/2012 - Rotlle de la Sala 123/2016)}

La sentència que analitzem jutja el cas d'una reclamació de responsabilitat patrimonial derivada d'una modificació de planejament en una àrea pertanyent a un antic pla parcial que va ser desclassificat i considerat sòl rústic. Més concretament, es va atacar la Resolució del conseller d'Urbanisme i Territori del Consell Insular de Mallorca, de 25 de juliol de 2012, en la qual s'inadmet per improcedent la reclamació de responsabilitat patrimonial formulada per la part reclamant el 25 d'abril de 2012 respecte a l'aprovació, cinc anys abans (el 26 d'abril de 2007), de les Normes subsidiàries d'Andratx (Mallorca), en les quals apareixien classificades com a sòl rústic una sèrie de parcel·les que havien pertangut a l'àmbit del Pla Parcial d'Urbanització de la Costa d'Andratx. Aquest pla parcial es va aprovar el 13 de gener de 1975 (sense que arribés a consolidar-se completament). Al seu torn, les parcel·les objecte de discussió havien estat adquirides el 1997 per la part demandant al preu de 9 euros $/ \mathrm{m}^{2}$.

Per ampliar el cas, recordarem que en el moment de la compra (el 1997), aquestes parcel-les ja tenien la classificació de sòl rústic protegit, en concret arran de la Llei 1/1991, de 30 de gener, d'espais naturals i de règim urbanístic de les àrees d'especial protecció de les Illes Balears (LEN), en vigor des del 10 de març de 1991.

L’Administració apel·lada, el Consell Insular de Mallorca, va aprovar definitivament el Pla Territorial Insular de Mallorca el 13 de novembre de 2004, que havia de subjectar-se a la LEN i, per tant, va mantenir-ne la desclassificació. Al seu torn, el Consell Insular de Mallorca (CIOTUPH) va aprovar definitivament les Normes subsidiàries d'Andratx el 26 d'abril de 2007, en què apareixien aquestes parcel·les amb l'esmentada classificació, és a dir, com a sòl rústic protegit. Això condueix a afirmar (com fa el Tribunal) que no van 
ser ni el Pla Territorial Insular de Mallorca de 2004 ni les Normes subsidiàries de 2007 els instruments que van classificar com a sòl rústic les tres parcel·les de la part litigant. Aquestes tres parcel·les ja eren sòl rústic abans de l'adquisició, com hem vist, a un preu propi de sòl en situació rural.

No obstant això, la part recurrent va continuar sostenint que la classificació de les seves parcel·les era sòl urbà. Per això, va instar un recurs en seu jurisdiccional, que va ser desestimat en la Sentència de la Sala núm. 258/2011, de 14 d'abril de 2011 —ROJ: STSJ BAL 294/2011 - ECLI: ES: TSJBAL: 2011:294-. És evident que, atès que és pacífic que la Sentència de la Sala núm. 258/2011 és ferma, l'ara part apel-lant va haver d'acceptar en aquell moment que les parcel·les que va adquirir eren sòl classificat com a rústic protegit, però no va ser així i, airejant la idea que diverses certificacions administratives recollien com a urbans els terrenys la seva propietat, afirma que va comprar induït per un error i que això hauria de ser compensat econòmicament per l'Administració. Així, amb aquesta pretensió, més d'un any després de la Sentència de la Sala núm. 258/2011, en concret el 25 d'abril de 2012, va presentar davant del Consell Insular de Mallorca una reclamació de responsabilitat patrimonial sense concretar quina indemnització pretenia, i es va limitar a afirmar que ja presentaria la valoració en un moment ulterior.

La Resolució del conseller d'Urbanisme i Territori del Consell Insular de Mallorca, de 25 de juliol de 2012, va inadmetre per improcedent la reclamació de responsabilitat patrimonial formulada el 25 d'abril de 2012. La part recurrent va instar la controvèrsia al Jutjat núm. 1, on va veure desestimat el recurs. El Jutjat va estimar que les certificacions a què al-ludeix la part reclamant eren de data posterior a la data en què va comprar les tres parcel·les, la qual cosa no lliga amb la idea que l'havien pogut induir a algun error a l'hora de comprar.

La sentència del Jutjat va ser recorreguda en apel-lació, i en la demanda la part reclamant va aprofitar per introduir motius d'oposició a la decisió administrativa que no van ser mostrats a la jutgessa ni en la demanda ni en les conclusions. Aquests detalls apunten que, amb l'aprovació de les Normes subsidiàries, la superfície protegida passa a ser més gran que en la LEN i en el PTIM. Com és natural, aquests motius no s'han pogut tractar en la sentència apel·lada.

En la demanda de 20 de desembre de 2012, pot veure's que, inexplicablement, no es va sol·licitar al Jutjat ni que s'estimés el recurs ni que s'anul·lés la resolució administrativa 
que es recorria. El que se sol- licitava al Jutjat era una indemnització que no es concretava "pels actes realitzats, que materialitzaven l'aprofitament urbanístic". I aquesta petició es va fer després d'una altra, que consistia que el Jutjat hauria de declarar en la sentència que la classificació dels terrenys de la part reclamant com a sòl rústic protegit en la Normes subsidiàries de 2007 i en el Pla Territorial Insular serien "contràries a la qualificació prevista en la Llei d'Espais Naturals". Tanmateix, hem vist que el 2012 aquest era un tema tancat, ja que la classificació dels terrenys del cas com a sòl rústic protegit no es va dur a terme ni amb les Normes subsidiàries de 2007 ni del Pla Territorial Insular, en què es reflecteix la classificació que va imposar el 1991 la LEN, amb la qual cosa, per descomptat, tampoc ja no es podia sostenir que fossin "contràries a la qualificació prevista en la Llei d'Espais Naturals".

El nucli final del raonament del Tribunal Superior és el següent:

[...] En l'apel·lació s'expressa la idea que la sentència apel·lada no ha entès què és el que el Sr. José Daniel vol i, a causa d'això, es considera que la sentència ara apel-lada no ha encertat la resposta apropiada per al cas del Sr. José Daniel.

La Sala no comparteix aquesta idea del Sr. José Daniel. Considerem que és la part apel-lant el que no ha entès la sentència apel-lada, que li respon directament i clarament a les seves pretensions. I ho fa per rebutjar-les, en primer lloc, perquè no tenien en compte el que devien, és a dir, la Sentència de la Sala núm. 258/2011; i, a més, perquè les certificacions a les quals al-ludeix el Sr. Jose Daniel eren de data posterior a la data en què va comprar les tres parcel-les.

Com és natural, no pot ser acceptat de cap manera que actes posteriors a la compra puguin haver induït el Sr. Jose Daniel a error en aquesta compra.

Per tant, la Sala accepta la decisió de la sentència apel·lada i accepta la base jurídica que la fonamenta.

Pot assenyalar-se igualment que, com que el termini per reclamar és d'un any, no cal dir que havia transcorregut ja àmpliament el 25 d'abril de 2012 no només respecte $\mathrm{a}$ la Llei CAIB 1/191 i el Pla Territorial de 2004, sinó també respecte a les Normes subsidiàries de 2007.

Arribats a aquest punt, compleix la desestimació de l'apel·lació.

Per tot això, el Tribunal desestima el recurs contenciós administratiu i indirectament reconeix la capacitat de la LEN, del PTIM i de les Normes subsidiàries d'Andratx per establir un bloc normatiu consolidat no atacable que no dóna dret a cap tipus d'indemnització respecte a determinades mesures de protecció de sòls no consolidats 
procedents de plans parcials no executats, sòls que es van convertir en zones de protecció especial.

\section{Sobre responsabilitat patrimonial derivada d'una anul·lació judicial de llicència} d'obres: la Sentència del Tribunal Superior de Justícia de les Illes Balears (número 412/2016), de 7 de juliol de 2016 (ID. Cendoj: 07040330012016100376, núm. procediment PO 175/2011 - Rotlle de la Sala 381/2015)

El cas que presentem en segon lloc té com a objecte la resolució dictada, de forma presumpta per la ficció legal del silenci administratiu, per l'Ajuntament de Sant Lluís (Menorca) que desestima la sol-licitud de responsabilitat patrimonial efectuada per la part reclamant el dia 10 de febrer de 2009.

En el present cas, l'Ajuntament de Sant Lluís va atorgar una llicència en data 3 de juny de 2004 per a la construcció d'un habitatge annex a una explotació agrària. L'esmentada llicència va ser objecte del Recurs contenciós administratiu núm. 127/2004, que va finalitzar amb la Sentència núm. 64/2006, de 2 de març de 2006, posteriorment confirmada pel Tribunal Superior de Justícia. La llicència va ser anul-lada i va arrossegarne els efectes, en els termes següents:

PRIMER: S'estima el recurs contenciós administratiu interposat pel Sr. Guillem Mercadal Gonyalons contra l'Acord de la Comissió de Govern de l'Ajuntament de Sant Lluís de 3 de juny de 2004 que va concedir llicència per a la construcció d'un habitatge annex a una explotació agrícola en la CARRETERA000 polígon NUM000 parcel·la NUM001.

SEGON: Es declara nul l'acte administratiu impugnat perquè no s'ajusta a l’ordenament jurídic [Sentència núm. 64/2006, de 2 de març de 2006].

Amb aquestes dades incontrovertides en vista de la sentència esmentada, sembla obvi que només es pot concloure que el dany que reclama la part recurrent no és indemnitzable, atès que no és antijurídic, en el sentit que la part recurrent té el deure de suportar-lo ja que havia construït l'esmentat habitatge quan ja existia un recurs contenciós administratiu pendent de resoldre, que tenia per objecte l'anul·lació de la llicència; aquesta anul·lació era perfectament possible, la qual cosa implica que el risc va ser assumit simplement per la part reclamant de responsabilitat patrimonial. I és que, en efecte, el recurs contenciós es va iniciar l'any 2004; així que, ja es prengui la data d'inici d'obres indicada per la part 
recurrent —novembre de 2005—, com l'assenyalada per l'Ajuntament demandat — gener de 2006-, l'esmentat recurs ja penjava. Ultra això, i quan les obres es trobaven a l'inici, es va dictar la sentència que anul·lava la llicència, per la qual cosa no s'entén la raó per la qual la part recurrent va decidir continuar les obres iniciades davant de la falta d'aparença de bon dret en l'atorgament de la mateixa llicència. A més, el Consorci, per protegir la legalitat urbanística en sòl rústic de l'illa de Menorca, també el 2006 va iniciar un expedient de restauració de la legalitat urbanística per demolir les obres d'edificació dutes a terme per la part recurrent.

Per totes aquestes raons, tant el Jutjat d'Instància com el TSJIB podrien haver apreciat culpa exclusiva de la víctima en la producció del dany relatiu al cost de la part construïda i el cost de la restauració del terreny a l'estat d'origen, que trenca el nexe causal exigit per al naixement de la responsabilitat patrimonial de l'Ajuntament de Sant Lluís en relació amb els esmentats danys. Tanmateix, com veurem a continuació, això no ha estat així, ja que s'ha modificat el raonament en un doble sentit, primer pel Jutjat i després pel TSJIB.

Efectivament, el Jutjat d'Instància va apreciar que hi havia responsabilitat patrimonial de l'Administració demandada quant a les despeses necessàries per a l'atorgament de la llicència que efectivament es va concedir (cost del projecte bàsic, del projecte d'execució, etcètera) i que, com hem vist, va ser anul·lada posteriorment en virtut de sentència.

La cronologia dels fets seria la següent:

El dia 21 d'octubre de 2008 la part reclamant va presentar sengles escrits de reclamació de responsabilitat patrimonial solidària a les seus administratives del Consell Insular de Menorca i de l'Ajuntament de Sant Lluís. La referida sol·licitud de responsabilitat patrimonial a l'Ajuntament de Sant Lluís va ser desestimada per la ficció legal del silenci administratiu. Posteriorment es va interposar el contenciós el dia 28 de juny de $2011 \mathrm{amb}$ la petició d'indemnització de la quantitat d'1.862.149,68 € per l'anul·lació de la llicència d'obres i de $177.900 €$ com a xifra estimativa per les despeses previstes de demolició, en el supòsit que ell s'hagués de fer càrrec de l'abonament de l'execució, així com de qualsevol altra despesa produïda per la construcció i demolició de l'habitatge.

Aquesta reclamació s'emparava en el fet que, atorgada una llicència d'obres per a la construcció d'un habitatge annex a una explotació agrícola per part de l'Ajuntament de 
Sant Lluís, aquesta llicència va ser anul-lada després judicialment, com ha quedat patent per la transcripció parcial de la sentència d'instància efectuada abans.

L'existència d'un procediment bifàsic, ateses les característiques descrites de la sol-licitud, va determinar la petició al mes de novembre de 2003 d'un informe vinculant al Consell Insular de Menorca, que no va elaborar de forma expressa. Es va entendre, doncs, atorgat per la ficció legal del silenci administratiu positiu.

L'atorgament de la llicència es va concedir per mitjà de 1'Acord de la Comissió de Govern de l'Ajuntament de Sant Lluís del dia 3 de juny de 2004, és a dir, més de sis mesos després d'haver sol·licitat l'esmentat informe al Consell Insular de Menorca.

Contra l'esmentat acord es va interposar un recurs contenciós administratiu que va acabar amb la Sentència núm. 64 de 2006 (JCA 1), de 2 de març de 2006. Al seu torn, es va interposar recurs d'apel·lació resolt mitjançant la Sentència núm. 214, de 6 de maig de 2008 (TSJIB), al Rotlle núm. 106 de 2006. La sentència va desestimar l'apel·lació i va confirmar la sentència d'instància.

En execució de les referides sentències, el dia 16 de gener de 2013, finalment, es va demolir l'habitatge i els seus annexos, data en què ja s'havia iniciat la controvèrsia sobre si era procedent o no la reclamació de responsabilitat patrimonial sol·licitada.

Així, el que es tracta de dilucidar ara és l'abast de la indemnització i de si comprèn les despeses realitzades de bona fe i només aquestes o, a més, si s'han d'incloure també les de construcció i posterior demolició de les obres dutes a terme a l'empara de la llicència declarada nul·la pels tribunals.

Per això, el TSJIB es basa en la sentència apel·lada i en la jurisprudència d'aquesta Sala sobre la matèria, que es recull, entre altres, en la Sentència de 9 d'abril de 2007, per referència a la de 20 de gener de 2005, segons la qual la indemnització de danys $\mathrm{i}$ perjudicis per causes d'anul·lació de llicències municipals (d'obra, edificació, etc.) és correlatiu lògic de tota revocació de llicències per tal causa, tal com preveien l'article 16 del Reglament de Serveis i l'article 172 de l'anterior Llei, i recollia l'article 232, paràgraf 1 del text legal vigent en el moment de produir-se els fets, així com l'article 38 del Reglament de disciplina urbanística (també vigent en aquell moment) en proclamar el principi de responsabilitat de l'Administració conforme al règim jurídic general, perquè és indubtable que l'anul·lació d'una llicència ocasiona al titular danys i perjudicis certs $\mathrm{i}$ 
determinables, perquè, en tot cas, suposa la impossibilitat de continuar duent a terme l'activitat autoritzada i fins i tot es pot arribar a demolir la part construïda.

Per això, és clar que l'administrat, en aquests supòsits, pateix una lesió patrimonial que és conseqüència directa de la manera d'obrar incorrecta de l'Administració. D'això en deriva la procedència de la indemnització, que com a regla ningú no discuteix segons la declaració de responsabilitat que els esmentats preceptes consagren en relació amb el principi constitucional consagrat en l'article 106 de la Constitució, 26 febrer i 14 març 80, 26-9-81 i 14-12-83, etc. Com veiem, el TSJIB no sembla que opti per l'aplicació de la doctrina de culpa compartida derivada de l'actuació imprudent de la part reclamant, ja que prossegueix amb les obres litigioses.

Efectivament, el Tribunal opina que, en aquesta matèria, la regla general té una important excepció en la norma que conté el número 2 de l'article 232 de l'esmentada llei (art. 39 del Reglament), ja que preceptua que "en cap cas no hi haurà indemnització si existeix dol, culpa o negligència greus imputables a la part perjudicada"; prova que ha d'anar a càrrec de qui l'al·legui — com a causa d'exoneració— d'acord amb les regles generals. I si és cert que, quan s'atorga una llicència que infringeix l'ordenament, ho és a petició de la part interessada i com regla de conformitat amb el projecte presentat — cosa que fa difícil la possibilitat d'al·legar desconeixement de la infracció (tret de casos d'ordenacions urbanístiques incompletes o confuses, etc.) - , tanmateix, això no és prou perquè la nova normativa no suposa una exempció total o absoluta de responsabilitat (davant el sistema anterior), sinó que exigeix l'existència de dol o culpa greu imputable a l'administrat. D'idèntica manera es pronuncien altres sentències reiterades, com la dictada per la Sala el 26 de setembre de 2000 (Rec. Cas. 3456/96 ), que exposa que la responsabilitat per llicències urbanístiques es determina, segons l'article 232 del Text refós de la Llei sobre règim del sòl i ordenació urbana de 9 d'abril de 1976, d'acord amb les normes que regulen amb caràcter general la responsabilitat patrimonial de l'Administració; per això, perquè sigui viable una pretensió indemnitzatòria d'aquesta naturalesa, s'ha d'haver produït un dany efectiu, avaluable econòmicament, antijurídic i individualitzable en relació amb una persona o grup de persones.

Quan es presenten aquestes circumstàncies, procedeix el dret a indemnitzar, sempre que no existeixi dol, culpa o negligència greu imputables a la part perjudicada — article 232 in fine del Text refós de 1976. 
Després d'entendre que existeix el dret a indemnitzar per les despeses ocasionades de bona fe, el TSJIB afirma que, en conseqüència, el dany reclamat és indemnitzable i que n'és responsable patrimonial l'Ajuntament de Sant Lluís. I a continuació determina el debat de la quantia que ha de satisfer en els termes següents:

CINQUÈ.- Quant a la quantia objecte d'indemnització a partir de la consideració que s'ha de produir la reparació integral dels danys i perjudicis, tal com afirmem a la nostra núm. 828 de 27 d'octubre de 2003 dictada a les actuacions 126 de 2001, "La indemnització per anul-lació de la llicència atén al principi de reparació íntegra i, en conseqüència, comprèn tots els danys realment produïts, això és, els honoraris del projecte i la direcció d'obres, les taxes municipals d'expedició de la llicència, les despeses de declaració d'obra nova, les despeses de naturalesa financera, les cessions, els costos de l'obra executada i del material no utilitzable, les despeses de demolició i el lucre cessant —sense que s'hi incloguin les meres expectatives".

Aquests i no d'altres, comprensius del dany emergent i el lucre cessant, doncs, han de ser els conceptes que s'han de tenir en compte per rescabalar l'administrat. Indemnització que, ara com ara, no podem quantificar correctament, ja que no hi ha fets degudament provats. No obstant això, pot, i així ha de fer-se, en tràmit d'execució de sentència, tal com va acordar també la sentència d'instància apel·lada en la part que va estimar parcialment el contenciós, si més no però amb la inclusió dels conceptes que diem.

Tot això, no obstant això, amb dues matisacions, la primera, que el límit temporal per l'abonament de les despeses derivades de la llicència i les obres dutes a terme en principi el marcaria la fermesa de la Sentència núm. 214 de 6 de maig de 2008 dictada al rotlle núm. 106 de 2006; a partir de la qual, doncs, no hi hauria dret a percebre cap despesa més dels efectuats; una altra segona, que com vulgui que hem dit que també s'havien d'incloure les despeses de la demolició produïda al mes de gener de l'any 2013 sempre, és clar i molt entès, que si aquesta no hagués anat en realitat a càrrec de l'Administració directament, ja que en aquest supòsit s'han d'excloure expressament.

Ara bé, malgrat el que avancem, és important tenir en compte definitivament com a límit temporal més adequat a aquests efectes la datació del 30 de maig de 2006 en què el Consorci per a la protecció de la legalitat urbanística va incoar l'expedient administratiu núm. NUM002 amb la pretensió de dur a terme la demolició de l'habitatge en construcció després de conèixer la Sentència de primera instància de 2 de març de 2006, finalment confirmada per la nostra de 2008, en què s'acorda, entre altres mesures, ordenar la suspensió immediata de les obres tal com es preveu, 
de forma taxativa, en els articles 61 i següents de la Llei 10/1990, de 23 d'octubre, de disciplina urbanística de la CAIB. El dia 27 d'abril anterior s'havia aixecat acta de la inspecció d'obres.

Fixació en execució que, en cap cas, no pot superar el quàntum interessat en la petita. També havíem assenyalat en la narració fàctica de la present l'existència d'un procediment bifàsic, ateses les característiques descrites de la sol-licitud, que va determinar la petició al mes de novembre de 2003 d'un informe vinculant al Consell Insular de Menorca que no es va produir de forma expressa. Es va entendre, doncs, atorgat per la ficció legal del silenci administratiu positiu.

Aquest fet, una vegada finalitzat el contenciós inicial de 2004 per la reiterada Sentència de 20 de maig de 2008, va determinar que el següent dia 21 d'octubre de 2008 el Sr. Indalecio presentés sengles escrits de reclamació de responsabilitat patrimonial solidària a les seus administratives del Consell Insular de Menorca i de l'Ajuntament de Sant Lluís - la derivació de la primera se substancia ara com ara a l'esmentat Jutjat Contenciós Administratiu núm. 1 dels de Palma.

En la primera instància es va adduir per la postulació de l'Ajuntament de Sant Lluís l'excepció de litisconsorci passiu necessari. Excepció que no va prosperar segons els termes del $2 \mathrm{n}$ dels fonaments de dret de la sentència apel-lada. Es deia que:

“Únicament es pot apreciar l'esmentada excepció quan la llei expressament imposa l'obligació de dirigir l'acció contra dues persones diferents i no és el cas d'actuacions, per la qual cosa la part recurrent podia triar contra qui havia de dirigir l'acció exercitada".

Punt no qüestionat en l'apel·lació presentada, potser a causa que el contenciós 29/2011 del referit Jutjat núm. 1 roman ara suspès des de la Provisió de 9 de novembre de 2015 i on es va acordar:

"Ja que la sentència que va recaure en el Procediment ordinari 175/2011 seguit en aquest jutjat pot tenir efectes prejudicials en la resolució que ha de recaure en aquest procés, se suspèn el present procediment fins que no es resolgui el recurs d'apel·lació que penja a la Sala presentat contra l'esmentada sentència".

Suspensió decretada una vegada tancat el període probatori del referit contenciós. En conseqüència, estimem parcialment l'apel-lació instada pel Sr. Indalecio i desestimem l'apel·lació presentada per l'Ajuntament de Sant Lluís i es donen per reproduïts quant a aquesta última els arguments efectuats fins ara i que suposen el rebuig de l'última de les esmentades.

Així les coses, la sentència implica que la part reclamant ha de ser indemnitzada per totes les despeses ocasionades, ja que era tributària d'una llicència urbanística de bona fe, 
anul·lada en seu judicial. L'Ajuntament de Sant Lluís ha d'indemnitzar: tots els danys realment produïts, això és, els honoraris del projecte i direcció d'obres, les taxes municipals d'expedició de la llicència, les despeses de declaració d'obra nova, les despeses de naturalesa financera, les cessions, els costos de l'obra executada i del material no utilitzable, les despeses de demolició i el lucre cessant — sense que incloure les meres expectatives-, encara que tot això amb els matisos del fonament de dret transcrit (cinquè) que pot implicar una minoració important en la quantia finalment que cal satisfer en aplicar una quota de responsabilitat a la part reclamant pels actes duts a terme quan es va produir la sentència d'anul·lació de la llicència i l'ordre de demolició.

Amb tot, conceptualment, la sentència suposa un gir important respecte de la indemnització establerta pel Jutjat Contenciós.

3. Sobre l'obligatorietat de construir una pantalla acústica en una carretera: la Sentència del Tribunal Superior de Justícia de les Illes Balears (número 455/2016), de 14 de setembre de 2016 (ID. Cendoj: 07040330012016100413, núm. procediment PO 059/2012 - Rotlle de la Sala 129/2016)

En el tercer cas que plantegem es va interposar un recurs contra la desestimació presumpta, per efectes del silenci, del recurs d'alçada presentat per la part demandant davant de la Presidència del Consell Insular de Mallorca en data 10 de gener de 2012 contra la desestimació presumpta de la sol-licitud presentada davant de la Direcció General de Carreteres del Consell Insular de Mallorca el 16 de setembre de 2011, en la qual interessava la construcció d'una pantalla acústica per a la protecció de la parcel·la i habitatge de la seva propietat, amb unes dimensions de 170 metres de longitud i 3,5 metres d'alçada.

El recurs davant de Jutjat del Contenciós Administratiu número 2 de Palma va obtenir la Sentència núm. 25/2016, de data 22 de gener, sentència que deia literalment en la seva decisió:

Que desestimo el recurs contenciós administratiu interposat per la procuradora $\mathrm{Na}$ Magdalena Cuart Janer, en nom i representació del Sr. Arcadio, contra la desestimació presumpta per silenci administratiu del recurs d'alçada presentat en data 10 de gener de 2012 contra la desestimació presumpta de la sol-licitud presentada en data 16 de setembre de 2011, sobre contaminació acústica. 
Sense imposició de costes.

Contra l'anterior sentència es va interposar un recurs d'apel·lació en termini i forma per la part, que va ser admès en ambdós efectes, seguit el recurs d'acord amb els tràmits de la Llei reguladora de la Jurisdicció Contenciosa Administrativa, i es va assenyalar el dia 3 de juny de 2016 per a la votació i decisió. D’altra banda, mitjançant la Provisió de la mateixa data de l'assenyalament, amb suspensió del termini per dictar sentència, la Sala va sotmetre a les parts la qüestió relativa a la possibilitat que existís una estimació per doble silenci, havent presentat al-legacions les parts litigants i es va assenyalar de nou per a votació i decisió el dia 9 de setembre de 2016.

Hem d'assenyalar que la Sentència apel·lada va desestimar el recurs contenciós administratiu interposat. Igualment, veiem que en l'escrit de demanda la part recurrent sol·licitava que s'anul·lés l'acte presumpte impugnat i que es condemnés el Consell Insular de Mallorca (CIM), principalment, a la construcció d'una pantalla acústica, i subsidiàriament, al pagament de 65.656,76 euros, més l'IVA corresponent, així com a la concessió de llicència per a les actuacions destinades a l'esmena de les deficiències relatives a la contaminació acústica soferta a la seva parcel·la.

El jutjador d'instància, en primer terme, raona que l'acció exercitada per l'actor no s'incardina en un supòsit de responsabilitat patrimonial de l'Administració, sinó davant de la petició derivada del pretès dret subjectiu a sol-licitar el compliment dels objectius de qualitat i emissions acústiques, per la qual cosa no resulta aplicable el termini de prescripció d'un any previst en l'article 142.5 de la Llei 30/1992. A continuació, esmenta la legislació estatal bàsica i la normativa autonòmica aplicable pel que fa al soroll, i conclou que a partir de la prova practicada no es desprèn que se superin els nivells de qualitat acústica, ja que s'ha efectuat únicament un mesurament en període estival, quan hi ha més trànsit, obtingut a l'exterior de l'habitatge, a 11 metres de distància, tractant-se d'una finca classificada com a sòl rústic, sense que l'ús residencial s'apreciï com a predominant. Per finalitzar, el jutjador manifesta que davant el silenci mostrat pel Consell Insular, hauria estat desitjable que l'Administració hagués valorat objectivament les circumstàncies del trànsit a la zona per decidir si era procedent dur a terme actuacions per pal-liar els efectes del soroll.

Com podem resumir de la sentència objecte d'anàlisi, als efectes de resoldre les qüestions controvertides, consistents a dilucidar l'existència o inexistència d'un deure corresponent 
al CIM, com a titular de l'autovia Dt-13, d'adoptar mesures contra la contaminació acústica quan aquestes són sol·licitades pels supòsits perjudicats, s'han de destacar les següents dades de fet que resulten acreditades a partir de l'expedient administratiu, de les al-legacions i diligències de prova, respectivament efectuades i practicades per les parts litigants:

1) El Sr. Arcadio, des del 20 de setembre de 2010, és propietari d'un immoble situat a la parcel·la NUM000 del polígon NUM001, del terme municipal de Binissalem, sobre el qual existeix una edificació destinada a habitatge unifamiliar, classificat pel Pla Territorial Insular de Mallorca com a "sòl rústic general" (SRG), dins de la unitat paisatgística 8 (UP- 8), mentre que les Normes subsidiàries de planejament de Binissalem el classifiquen igualment com a sòl rústic comú, amb categoria d"'àrea d'interès agrari E”, amb una franja paral·lela a l'autovia classificat com a sòl rústic protegit (APT) i una altra franja APT que discorre paral·lela al camí des Pou d'en Torrents.

2) La finca originària va ser objecte d'una expropiació forçosa per executar l'autovia Ma-13, després d'haver assolit un acord sobre l'apreuament entre l'Administració expropiant i l'anterior propietari el 17 de març de 1999. L'autovia va ser posada en funcionament en els anys 1994-1995.

3) L'habitatge es troba entre 32,5 i 37 metres lineals de distància de l'autovia.

4) El 26 de gener de 2011, l'advocat de l'actor va presentar un escrit davant de la Direcció General de Carreteres del Consell Insular de Mallorca, en el qual denunciava el nivell d'immissió acústica suportat al seu habitatge a consequiència de l'autovia, interessat que s'efectuessin mesuraments i s'executessin les mesures correctores pertinents per eliminar o disminuir el soroll, mitjançant la instal·lació de pantalles. S'acompanyava d'un mesurament sonomètric, sense indicar-ne l'autoria. Aquesta petició va ser reiterada en escrits presentats el 7 d'abril de 2011 (també dirigit a l'Ajuntament de Binissalem) i el 16 de setembre de 2011, al qual es va adjuntar un informe d'avaluació acústica realitzat per l'entitat "Centro de Estudio y Control de Ruido S.L." (CECOR) durant 24 hores, en què se sol-licitava la construcció d'una pantalla acústica de 170 metres de llarg per 3,5 metres d'alçada. L'assaig per calcular el nivell d'immissió de soroll ambiental es va dur a terme el 30 de juny de 2011, durant 24 hores, des d'un punt exterior de l'habitatge, i va oferir un resultat de mitjana de $68 \mathrm{dbA}$ durant el dia, $67,1 \mathrm{dbA}$ a la tarda i $62,7 \mathrm{dbA}$ a la nit.

5) El 10 de gener de 2012 va interposar un recurs d'alçada davant la desestimació presumpta de la seva reclamació, dirigit a la Presidència del Consell Insular, el qual tampoc no va rebre resposta. 
Com s'expressa en la Sentència del TSJIB número 314/2014, de 29 de maig, en la qual s'examinava la conformitat a dret de l'Acord adoptat pel Ple del Consell Insular de Mallorca de 2 de juny de 2011, que va aprovar definitivament el mapa estratègic de sorolls de l'eix Ponent- Llevant, carreteres Ma-1, Ma-19 tram Palma-Llucmajor i Ma-20:

El mandat constitucional de protecció de la salut i del medi ambient en els seus articles 43 i 45, i la regulació europea en matèria de sorolls plasmada en la Directiva 2002/49/CE de 25 de juny, han cristal-litzat en la Llei 37/2003 de 17 de novembre reguladora dels sorolls, tot això amb la finalitat de garantir una bona qualitat de vida als ciutadans i el gaudi d'un medi ambient saludable en la doble faceta d'emissió de sorolls com de vibracions.

Per això, les administracions estan obligades a prevenir, vigilar i reduir la contaminació acústica, per evitar i reduir els danys que poden derivar-se per a la salut humana, els béns o el medi ambient (art. 1) i a tal efecte han d'elaborar, aprovar i revisar els corresponents mapes de soroll i la delimitació de zones de servitud acústica (art. 4 a) i b)) i executar mesures previstes en el pla (apartat f).

Respecte a la intervenció dels ens públics sobre els emissors acústics, entre els quals s'inclouen les infraestructures viàries, ja que hi discorre el trànsit rodat, l'article 18 de la Llei estatal 37/2003, de 17 de novembre, del soroll (LR), de caràcter bàsic, disposa que les administracions públiques competents han d'aplicar, en relació amb la contaminació acústica produïda o susceptible de produir-se pels emissors acústics, les previsions que conté aquesta llei i en les seves normes de desplegament en qualsevol de les actuacions previstes en la normativa ambiental aplicable. Tot això es desplega profusament en diferents textos legals i reglamentaris, i es conclou que en les àrees acústiques contaminades les administracions competents han d'adoptar les mesures necessàries per a la millora acústica progressiva del medi ambient fins a assolir l'objectiu de qualitat establert, mitjançant l'aplicació de plans zonals específics a què es refereix l'article 25.3 de la Llei 37/2003, de 17 de novembre.

A partir de tot això es demostra que l'assaig per calcular el nivell d'immissió de soroll ambiental aportat per la part actora va oferir un resultat de mitjana durant 24 hores de 68 dbA durant el dia, 67,1 dbA a la tarda i 62,7 dbA a la nit, quan els límits es troben en 55 db de dia i $45 \mathrm{db}$ de nit, d'acord amb la taula que conté l'article 6 del Decret. així, se superaven en 13 i $12 \mathrm{db}$, respectivament, els nivells màxims assenyalats de dia (ampliables fins a $71 \mathrm{db}$ ), i en més de $15 \mathrm{db}$ els nivells màxims en horari nocturn (fins a 
60db). En tot cas, els resultats dels mesuraments sonomètrics realitzats a instàncies de la part interessada, davant de la inactivitat mostrada pel Consell Insular (malgrat haver-se sol-licitat que les realitzés en diverses ocasions, mitjançant escrits presentats el 26 de gener, 7 d'abril i 17 de setembre de 2011) indiquen l'existència de contaminació acústica. Sobre aquesta quiestió, el TSJIB critica el fet que el CIM havia mostrat una total inactivitat i passivitat sobre això.

Se'n desprèn l'obligació del CIM de construir la pantalla acústica. No obstant això, el TSJIB abunda en la falta de resolució del recurs d'alçada contra un acte presumpte i manifesta:

Pel que concerneix als efectes del silenci administratiu respecte del recurs d'alçada formulat, al seu torn, contra una resolució presumpta, l'article 43.2 de la Llei 30/1992, de 26 de novembre, de règim jurídic de les administracions públiques i del procediment administratiu comú (d'ara endavant, LPAC, modificada per la Llei 4/1999, de 13 gener), disposa que: "Els interessats podran entendre estimades per silenci administratiu les seves sol-licituds en tots els casos, tret que una norma amb rang de llei o norma de dret comunitari europeu estableixi el contrari. Queden exceptuats d'aquesta previsió els procediments d'exercici del dret de petició, a la qual es refereix l'article 29 de la Constitució, aquells l'estimació dels quals tingués com a consequiència que es transferissin a la part sol-licitant $o$ a terceres parts facultats relatives al domini públic o al servei públic, així com els procediments d'impugnació d'actes i disposicions, en els quals el silenci tindrà efecte desestimatori. No obstant això, quan el recurs d'alçada s'hagi interposat contra la desestimació per silenci administratiu d'una sol·licitud pel transcurs del termini, s'entendrà estimat si, arribat el termini de resolució, l'òrgan administratiu competent no en dicta resolució expressa".

Per la seva part, l'article 115.2 LPAC determina que "El termini màxim per dictar i notificar la resolució és de tres mesos. Transcorregut aquest termini sense que recaigui resolució, es podrà entendre desestimat el recurs, excepte en el supòsit previst a l'article 43.2 , segon paràgraf."

Com a resulta de l'examen de l'expedient administratiu, l'advocat del Sr. Arcadio va presentar el 26 de gener, el 7 d'abril i el 17 de setembre de 2011 davant de la Direcció General de Carreteres del Consell Insular de Mallorca una sol-licitud perquè s'efectuessin mesuraments dels nivells sonors suportats al seu habitatge, $\mathrm{i}$ perquè s'adoptessin les mesures correctores oportunes, en què indicava la instal·lació de pantalles de protecció acústica. 
Des de l'última reclamació de setembre de 2011, transcorregut el termini màxim supletori de sis mesos previst en l'article 42.2 LPAC per dictar i notificar la sol-licitud, el sol·licitant va interposar recurs d'alçada davant la denegació per silenci de la seva petició, sense que tampoc recaigués resolució expressa de l'esmentat recurs interposat davant el superior jeràrquic.

Per tant, ha d'entendre's que la sol-licitud del recurrent havia estat estimada per efecte de l'anomenat "doble silenci", i, en conseqüència, la resolució expressa només podia tenir sentit estimatori de les pretensions de l'actor, ja que l'excepció al silenci positiu prevista a l'article 43.2 LPAC no opera en el supòsit de la desestimació presumpta del recurs d'alçada formulada per l'acte presumpte, que per aplicació de la regla excepcional als efectes positius del silenci en els procediments iniciats a sol-licitud dels particulars, produeix efectes negatius per a la part sol-licitant.

Les consideracions anteriors obliguen l'estimació del present recurs d'apel·lació i del recurs contenciós administratiu, per la qual cosa el Consell Insular de Mallorca haurà de construir una pantalla acústica per protegir la parcel·la i habitatge propietat de l'actor.

Per tot això el TSJIB resol:

1r) ESTIMAR el recurs d'apel·lació interposat per la representació processal del $\mathrm{Sr}$. Arcadio, contra la Sentència dictada pel Jutjat núm. 2 de Palma, núm. 25/2016, de 22 de gener, que es revoca.

2n) S'ESTIMA el recurs contenciós administratiu, ja que no és conforme a dret la resolució administrativa impugnada, i l'anul·la.

3r) ES RECONEIX EL DRET de l'actor que el Consell Insular de Mallorca construeixi una pantalla acústica per a la protecció davant el soroll sofert a la parcel·la i habitatge propietat de l'actor.

La resolució és interessant tant des del punt de vista ambiental del dret a obtenir una qualitat ambiental acústica adequada i protegida per la legislació del soroll, com per la qüestió procedimental plantejada del doble silenci. 


\section{Sobre obres il•legals i ordres de demolició: la Sentència del Tribunal Superior de Justícia de les Illes Balears (número 405/2016), de 6 de juliol de 2016 (ID. Cendoj: 07040330012016100370, núm. procediment PO 013/2010 - Rotlle de la Sala 178/2016)}

En el quart cas que plantegem es va interposar un recurs contra les resolucions recaigudes en l'expedient 2005/103 de la Comissió Insular d'Ordenació del Territori, Urbanisme i Patrimoni Històric del Consell Insular de Mallorca, de data 27 de febrer de 2009, per les quals es van imposar sancions per la comissió de presumptes obres il·legals al predi Biniatzent de Baix al municipi de Mancor de la Vall (Mallorca) alhora que s'acordava la demolició de les esmentades obres, i, contra la resolució expressa del recurs acordada pel Consell Executiu del CIM de data 2 de juny de 2010 que desestima el recurs d'alçada interposat contra la resolució sancionadora.

La Sentència número 77, de 17 de febrer de 2016, dictada pel Jutjat Contenciós Administratiu 2 de Palma, deia literalment en la seva decisió:

Que estimo parcialment el recurs contenciós administratiu interposat pel procurador Sr. Juan José Pascual Fiol, en nom i representació del Sr. Sebastián, contra les resolucions recaigudes en l'expedient NUM000 de la Comissió Insular d'Ordenació del Territori, Urbanisme i Patrimoni Històric del Consell Insular de Mallorca, de data 27 de febrer de 2009, per les quals se li va imposar una sanció per la comissió de presumptes obres il-legals al predi DIRECCION000 (Mancor de la Vall) alhora que es va acordar la demolició de les esmentades obres, i, contra la resolució expressa del recurs acordada pel Consell Executiu del CIM de data 2 de juny de 2010; i en conseqüència, es redueix l'import de la sanció imposada a la suma total de $171.333,68$ euros.

Que estimo el recurs contenciós administratiu interposat pel procurador Sr. Juan José Pascual Fiol, en nom i representació del Sr. Calixto, contra les resolucions recaigudes a l'expedient NUM000 de la Comissió Insular d'Ordenació del Territori, Urbanisme i Patrimoni Històric del Consell Insular de Mallorca, de data 27 de febrer de 2009, per les quals se li va imposar una sanció per la comissió de presumptes obres il·legals al predi DIRECCION000 (Mancor de la Vall) alhora que s'acordava la demolició de les esmentades obres, i, contra la resolució expressa del recurs acordada pel Consell Executiu del CIM de data 2 de juny de 2010; i en conseqüència, deixo sense efecte la sanció que li va ser imposada.

Declaro la inadmissibilitat parcial del contenciós interposat pel Sr. Sebastián, quant a l'ordre de demolició, per haver esdevingut ferm. 
Es mantenen la resta de pronunciaments continguts en les resolucions impugnades.

Sense expressa imposició de costes.

Contra l'anterior resolució es va interposar recurs d'apel·lació en termini i forma per la part demandada, el Consell Insular de Mallorca, del qual es va donar trasllat a la part demandant, que es va oposar a l'apel·lació i alhora es va adherir a l'apel·lació que, admesa en ambdós efectes, sense que cap de les parts proposés la pràctica de prova, seguit el recurs d'acord amb els tràmits de la Llei reguladora de la jurisdicció contenciosa Administrativa. Les actuacions concluses van quedar per dictar sentència, i es va assenyalar, per a la votació i decisió, el dia 5 de juliol de 2016.

Com a antecedents fàctics rellevants, interessa recordar:

Que a consequiència del procediment sancionador i de disciplina urbanística amb motiu d'unes obres executades sense llicència en una zona de sòl rústic amb categoria d'àrea natural d'especial interès (ANEI), el Consell Insular de Mallorca, per mitjà de la Comissió Insular d'Ordenació del Territori, Urbanisme i Patrimoni Històric, en subrogació de l'Ajuntament i per inactivitat d'aquest consistori, va dictar dues resolucions de data 27 de febrer de 2009, per les quals, en una es van imposar sancions per la comissió de presumptes obres il·legals, i en l'altra es va acordar la demolició de les esmentades obres.

Que en data 2 d'abril de 2009, el Sr. Sebastián va interposar un recurs d'alçada contra la Resolució sancionadora de data 27 de febrer de 2009, interessat que es declarés la nul·litat de l'expedient sancionador i, subsidiàriament, que es revisés d'ofici i s'anul·lés la resolució sancionadora perquè se suspengués el procediment mentre que no finalitzés la legalització de les obres.

Subsidiàriament a tot l'anterior, se sol·licitava que la quantia de la sanció fos de 9.224,93 $€$, és a dir, el 5\% de la valoració de l'obra executada, o, subsidiàriament, en la quantia de $12.494,70 €$ o $92.249,25 €$.

Que mitjançant la Resolució del Consell Executiu del CIM de data 2 de juny de 2010, es va desestimar el recurs d'alçada interposat contra la resolució sancionadora.

Davant de l'anterior, es va interposar un recurs contenciós administratiu que indicava que aquesta desestimava el recurs d'alçada interposat contra les dues resolucions de data 27 de febrer de 2009, això és, la resolució que imposa sanció i la resolució que acorda la demolició de les obres. 
La sentència aquí apel·lada, al marge d'exculpar un altre sancionat per motius que no afecten l'apel·lació, va declarar:

1r) Inadmissible el recurs contenciós administratiu interposat contra l'ordre de demolició de data 27.02.2009, ja que no havia estat recorreguda en temps i forma. Es considera que el recurs d'alçada interposat en data 2 d'abril de 2009 ho era exclusivament contra la resolució sancionadora de la mateixa data, però no contra la resolució que n'acorda la demolició.

2n) Que era procedent estimar parcialment el recurs interposat contra la sanció, i rebaixar l'import de la multa al 50\% en aplicació del que disposen els articles 45 i 46 de la llavors vigent Llei 10/1990, de disciplina urbanística de la CAIB.

El Consell Insular de Mallorca interposa recurs d'apel·lació contra el pronunciament pel qual s'acorda rebaixar l'import de la multa al 50\% del valor de les obres executades il-legalment. Se sol-licita que es mantinguin les multes en la quantia establerta per l'Administració. Concretament, s'invoca que una vegada que resulta admès que el fet infractor consisteix en l'execució d'obres sense llicència i que aquestes obres es van dur a terme sobre espais protegits (ANEI concretament), no són aplicables els articles 45 i 46 esmentats en la sentència apel-lada — referits a l'execució d'obres sense llicència en espais no especialment protegits-, sinó que és aplicable l'article 47, que expressament preveu que, en tals supòsits d'obres en sòls o edificacions protegides, la sanció de multa ha de ser del $100 \%$ al $200 \%$ del valor de les obres.

Al seu torn, la representació del particular s'oposa al recurs d'apel·lació i, a més, formula l'adhesió a l'apel·lació, i interessa que la sentència es revoqui pel que fa al tercer pronunciament (declaració d'inadmissibilitat parcial del contenciós quant a l'ordre de demolició) perquè al seu lloc es declari admissible i, ja quant al fons, que s'anul·li l'ordre de demolició perquè aquesta ordre no es pot acordar sense previ pronunciament sobre la sol-licitada legalització de les obres.

La infracció comesa consisteix en l'execució d'obres sense llicència urbanística (art. 27.1.b de la LDU 10/1990). La infracció es va classificar com a greu perquè afectava béns i interessos protegits. No es discuteix la comissió de la infracció, com tampoc no es discuteix que es va cometre sobre sòl especialment protegit (ANEI). Això últim és rellevant als efectes de la imposició de la quantia de la sanció que s'ha d'establir: es reconeix que es van dur a terme obres en sòl rústic de protecció especial i valor ambiental. 
La resolució administrativa sancionadora va desglossar les obres infractores en dos blocs: $a$ ) obres de construcció d'una bassa i $b$ ) resta d'obres.

Per a les primeres es va estimar que, de conformitat amb l'article 47 de la Llei 10/1990, eren sancionables amb multa del $100 \%$ al $200 \%$ del valor de les obres i, com que no es van presentar ni circumstàncies agreujants ni circumstàncies atenuants, es va imposar sanció a la mitjana de la franja, això és, del 150\% del valor de les obres.

Per a les segones es va estimar que, també de conformitat amb l'article 47 de la Llei 10/1990, eren sancionables amb multa del 100\% al 200\% del valor de les obres i, com que aquí sí que es presentava un agreujant (concretament el de l'art. 34.1 de LDU per no haver acatat l'ordre de suspensió de les obres), procedia la imposició de multa al $200 \%$ del valor.

Tanmateix, la sentència apel·lada redueix l'import de les dues sancions al 50\% del valor de les obres. Els arguments del Jutjat impliquen que, si se seguís el seu criteri, tindria la mateixa consideració l'execució d'obres sense llicència en sòl especialment protegit que les executades en sòl sense l'esmentada consideració, quan l'article 38 i l'anàlisi comparativa entre els articles 45 i 47 ja evidencien que no és així. Però no només això, sinó que la sentència, després d'apreciar - erròniament - que la franja sancionadora era la de l'article 45 (del 50\% al 100\% de les valor de les obres), aprecia que s'ha d'imposar el mínim de la franja (el 50\%). Tampoc no és encertat el criteri d'imposar la sanció mínima, ja que l'article 34 ja regula els criteris de graduació de la sanció, conforme als quals, si es presenta alguna circumstància agreujant, la sanció s'imposa en el grau màxim (art. 34.1); si es presenta alguna circumstància atenuant, la sanció s'imposa en el grau mínim (art. 34.2); per la qual cosa, finalment, si no es presenten circumstàncies atenuants o agreujants, per exclusió s'ha d'imposar en grau mitjà.

En canvi, els arguments de la Sala, per resoldre aquesta qüestió són els següents:

En qualsevol cas, i encara que l'extemporània invocació d'un motiu d'impugnació que es va haver de realitzar en la instància ja obliga al seu rebuig, tanmateix hem de precisar que rectifiquem la doctrina que contenia aquella sentència (l'altra esmentada, la núm. 381/2015 de 3 de juny, part de supòsit diferent), ja que el joc de l'article 34 LDU condueix a l'esquema següent: 1r) si es presenta alguna circumstància agreujant, la sanció s'imposa en el grau màxim (paràgraf 1r); 2n) si es presenta alguna circumstància atenuant, la sanció s'imposa en el seu grau mínim (paràgraf 2n); 3r) en conseqüència, si no hi ha ni agreujants ni atenuants, s'ha d'imposar en el 
seu grau mitjà, ja que, altrament, si s’imposa en el seu grau mínim la sanció per infracció sense circumstàncies modificatives, s'equiparen incorrectament als casos en què es presenten atenuants.

La representació del Sr. Sebastián en l'oposició al recurs d'apel·lació invoca que la sanció agreujada de l'article 47 no és aplicable a supòsits d'obres que, com el cas, són legalitzables, encara que no se sol-liciti la legalització en termini (supòsit $f$ de l'art. 45).

No és així, en els supòsits de l'article 47, l'única reducció possible a la sanció inicialment prevista (del 100\% al 200\%) és la reduïda del 5\% quan les obres puguin ser objecte de legalització i que l'esmentada legalització s'hagi sol·licitat en termini i no s'hagi desobeït l'ordre de paralització. Això es desprèn que el paràgraf $2 \mathrm{n}$ de l'art. 47 exclogui la reducció al 5\% en els supòsits dels apartats f) i g) de l'article. 45. Concretament, el segon paràgraf de l'article 47 preveu que "si aquestes obres o instal-lacions poden ser objecte de legalització, la sanció és del 5\% del valor de les obres realitzades o del terreny, segons correspongui, excepte en els casos previstos en els epígrafs f) i g) de l'article 45 d'aquesta llei.

En el cas, no es van parar les obres malgrat el requeriment de l'Administració (quant al grup d"'altres obres") ni es va sol-licitar la legalització en termini (quant a les obres de la bassa), per la qual cosa no podia aplicar-se la reducció al 5\%, única reducció possible en obres greus com la del cas, això és, les executades sobre espais protegits.

Per això, esdevé irrellevant tota l'argumentació expressada per la representació del Sr. Sebastián respecte a les vicissituds en les gestions encaminades a la legalització de les obres. A efectes de la sanció, no interfereixen perquè, repetim, només incidirien per a una possible reducció al 5\% en el cas que no operessin les excepcions (ordre de paralització desobeïda o sol-licitud de legalització en termini), però aquí operen. La mateixa part apel-lant reconeix que va instar la legalització fora del termini concedit (paràgraf $2 \mathrm{n}$ de la pàg. 6 de l'escrit d'apel·lació).

Una vegada que no és possible l'aplicació de la sanció reduïda al 5\% i que, per tant, s'ha d'imposar a la franja del $100 \%$ al $200 \%$, la graduació depèn dels agreujants i dels atenuants. Doncs bé, la sentència —encara que sigui sobre l'errònia sanció de l'art. 45- determina que s'imposi en el grau mitjà (50\%) però sense explicar el perquè. No se sap si és perquè s'aprecia que no hi ha ni agreujants ni atenuants o perquè es presenten les dos, de manera que es compensen.

La imposició de la sanció en el grau mitjà en la sanció referida a la bassa, no ofereix discussió perquè és la que ha aplicat la mateixa Administració. 
La imposició de la sanció en el grau màxim en la sanció referida a les "altres obres" es justifica en la resolució sancionadora per la concurrència d'un agreujant, concretament el de l'article 34.1 de LDU per no haver acatat l'ordre de suspensió de les obres. La sentència apel-lada reconeix la procedència d'aquest agreujant i no ens indica quin suposat atenuant es presentaria, per la qual cosa no hi havia cap altra possibilitat que mantenir la multa en el grau màxim. La representació del Sr. Sebastián suposa que el Jutjat va atendre la concurrència dels atenuants "invocats en la demanda", però ni en la demanda ni en l'apel·lació no trobem la cita i l'aplicació al cas d'alguns dels de l'article $34,2^{\circ}$ i 3 r LDU. En qualsevol cas, ni el culpable no va fer actuacions per minimitzar el dany abans d'iniciar les actuacions inspectores; ni es pot invocar desconeixement tècnic davant d'una infracció tan bàsica i elemental (la necessitat d'obtenir llicència abans d'executar obres); tampoc no afecta el benefici econòmic que es derivi de la infracció. En definitiva, no es presenta cap atenuant.

És procedent, per tant, l'estimació del recurs d'apel·lació del Consell Insular de Mallorca.

Per tot això, el TSJIB decideix estimar el recurs d'apel-lació interposat per la representació processal del Consell Insular de Mallorca i determina la sanció en els termes establerts en els raonaments de dret a dalt transcrits, en consideració a la gravetat de les infraccions comeses en sòl rústic d'especial protecció (ANEI).

\section{Sobre imputació de despeses per execució subsidiària: la Sentència del Tribunal} Superior de Justícia de les Illes Balears (número 422/2016), de 12 de juliol de 2016 (ID. Cendoj: 07040330012016100358, núm. procediment PO 179/2012 - Rotlle de la

\section{Sala 203/2016)}

La cinquena sentència seleccionada fa referència al recurs interposat contra la Resolució de 8 de juny de 2012 del conseller executiu del Consell Insular de Mallorca d'Urbanisme i Territori i president de l'Agència de Disciplina Urbanística, per la qual es va desestimar el recurs d'alçada formulat contra la Resolució de 13 de febrer de 2012 del director gerent d'aquesta Agència de Disciplina Urbanística del Consell Insular de Mallorca, per la qual es liquidaven a la part recurrent les despeses de l'execució subsidiària de la demolició d'un habitatge unifamiliar aïllat i il·legalitzable, al terme municipal de Campanet (Mallorca). 
La part recurrent, com a consequiència de l'execució d'una sèrie d'obres clandestines en sòl rústic protegit, el 2004 va resultar obligada a dur a terme la demolició corresponent i la restauració dels terrenys al seu estat natural. Aquesta obligació s'origina en una ordre d'execució que concedia un termini de tres mesos i quinze dies per materialitzar-la. Tanmateix, la part recurrent no va complir la seva obligació, ni en el termini assenyalat ni en cap moment. Aquest incompliment s'havia de traduir que el Consell Insular de Mallorca, s'encarregués de l'execució de la demolició amb càrrec a l'infractor. Per això, va caler esperar, com ja dèiem, set anys, és a dir, fins al 2011. Durant aquells set anys transcorreguts la part infractora recurrent va estar obligada a complir una ordre que continuava vigent.

És evident que davant de tal dilació en materialitzar una obligació (entre 2004 i 2011), una vegada que el 2011 va ser iniciada la tramitació de l'execució subsidiària ja no estava permès el compliment tardà de la part recurrent, sinó que el que li tocava llavors era ferse càrrec del cost d'aquesta execució subsidiària tal com preveu la legislació en matèria de disciplina urbanística.

En vista del resultat de les seves accions d'incompliment, la part recurrent intenta una tàctica desesperada discrepant de la quantitat girada per la demolició en fase d'execució subsidiària i discrepant d'aspectes procedimentals.

Sobre això, d'una banda el Tribunal respecta la possibilitat de discrepar respecte del cost d'execució, però recorda a la part recurrent que va tenir set anys per dur a terme pels seus propis mitjans la demolició associada a l'expedient de disciplina urbanística i no ho va fer. Per això el fet que el cost hagi superat les previsions inicials no té cap rellevància, ja que el que importa és que la quantitat girada per aquest concepte estigui degudament justificada.

Quant a la discrepància procedimental i a la metodologia seguida per contractar l'execució subsidiària per part de l'Administració, ens situa davant d'una controvèrsia inadmissible com a conseqüència de la mateixa infracció i ordre d'execució subsidiària. Doncs bé, sobre aquesta discrepància, la sentència apel-lada va desestimar el recurs, però com a novetat en l'apel·lació, la part recurrent esgrimeix, en primer lloc, que mereixia una liquidació provisional que no es va dur a terme, sobretot en vista de la diferència entre el contracte adjudicat i la liquidació girada. Sobre això, cal assenyalar que, com s'indica a la part apel·lant, la pràctica d'una liquidació provisional no és una obligació que la llei imposi a l'Administració actuant sinó que aquesta pot o no realitzar-la, sense que el fet 
de dur-la a terme o no o no depengui de la quantia del contracte adjudicat —article 98.4 de la Llei 30/1992.

Segons afirma el Tribunal:

Com una manifestació de la seva desorientació, el Sr. Sebastián al-ludeix també que l'Administració hauria sacrificat en el cas els drets que se li reconeixen en l'article 35.e) de la Llei 30/1992. Però el Sr. Sebastián no concreta res més i resulta que aquest precepte es refereix a la possibilitat de la part afectada de presentar al-legacions o documents a tota hora del procediment, la qual cosa que no consta que se li hagués impedit en el cas. Una altra cosa és que el Sr. Sebastián potser confongui aquest dret que la Llei li brinda amb l'obligació de l'Administració actuant d'obrir un tràmit d'audiència prèvia a la liquidació. El cert és que, iniciat l'expedient, l'Administració va atorgar un tràmit d'audiència, però no és previst per la Llei un tràmit d'audiència prèvia a la liquidació. Per tant, aquest tràmit no se li va obrir, al Sr. Sebastián.

També es qüestiona que el recurs d'alçada presentat per la part apel·lant fos informat per qui havia subscrit la liquidació, invocant sobre això l'article 13.2.c) de la Llei 30/1992. Però aquesta norma impedeix que el recurs d'alçada es decideixi per delegació, la qual cosa no és el cas, ni pot confondre's amb el cas que sí que es dóna, que és el que la notificació de la liquidació la subscrigui el secretari de l'Agència per delegació del secretari general del Consell i l'informe al recurs d'alçada el subscrigui el director gerent. Dit això, cal assenyalar també que els dubtes que abriga la part recurrent no tenen cap raó de ser. Sense que en el cas ho sigui, era perfectament possible jurídicament que la resolució del recurs d'alçada es basés completament en l'informe del director gerent, i això perquè el que la llei protegeix en l'article 13.2.c) de la Llei 30/1992 no és sinó la separació entre l'òrgan que dicta la resolució originària i l'òrgan que dicta la resolució del recurs d'alçada, i és lògic que el recurs d'alçada l'informi qui va dictar la resolució recorreguda.

Per tot això, el Tribunal acaba argumentant que:

Posades així les coses, i sent pacífic que el cost de l'execució correspon al Sr. Sebastián —articles 96.1.b ) i 98 de la Llei 30/1992 i articles 66.1 i 68 de la Llei CAIB 10/1999_, no es pot acceptar al Sr. Sebastián la legitimació per a la defensa dels hipotètics drets dels competidors amb l'entitat adjudicatària del contracte del 
cas, la qual cosa es deu al que ja és ben sabut, això és, que el Sr. Sebastián no era partícip en aquesta convocatòria.

També ocorre en el cas que la formula contractual operada va ser la recollida en un model destinat amb habitualitat als contractes d'execució d'obres, en què els costos d'eliminació i tractament de residus, pot dir-se planerament, que no tenen importància, mentre que en els contractes com el del cas, corresponent a obra de restauració dels terrenys al seu estat natural, que inclou, com és lògic, les demolicions corresponents, els esmentats costos són importantíssims.

Per tant, és natural que el contractista es faci càrrec d'aquestes despeses al contracte d'obres de construcció i no al contracte d'obres de restauració dels terrenys al seu estat natural, que és el que ha passat en aquest cas, en què ni tan sols no figuren en l'oferta a la qual es va adjudicar el contracte. Igualment passa amb les despeses de descontaminació i retirada i tractament dels residus de demolició i construcció.

Finalment, pel que fa a què és el que s'havia de demolir, sobre el que la part recurrent mostra la seva disconformitat amb el que ha ocorregut, se'ns pot dir que la discrepància s'assenta en la idea equivocada que la demolició no assolís, és a dir, no comprengués, totes les actuacions que sí que són necessàries per a la reposició dels terrenys al seu estat natural, alterat per les obres clandestines que l'infractor va dur a terme oportunament.

6. Sobre restitució de la legalitat urbanística i de la realitat física alterada: la Sentència del Tribunal Superior de Justícia de les Illes Balears (número 439/2016), de 26 de juliol de 2016 (ID. Cendoj: 07040330012016100383, núm. procediment PO 187/2012 - Rotlle de la Sala 061/2016)

El sisè i últim cas que plantegem consisteix en la interposició de recurs contra la Resolució dictada per la batllia de l'Ajuntament de Sant Joan de Labritja (Eivissa), el 23 de juliol de 2012, que resol i desestima el recurs de reposició interposat contra la resolució d'expedient sancionador i de reposició de la legalitat urbanística contra l'entitat AIBS DOS CORTIJO DOS, S.L. Aquests recurs després va ser ampliat a l'ordre de demolició immediata de les obres dutes a terme en virtut del Decret de batllia de 25 de maig de 2012, que concedia a la propietat un termini d'un mes per executar ella mateixa l'esmentada demolició. 
El Jutjat número 1 Contenciós Administratiu de Palma de Mallorca va dictar la Interlocutòria núm. 291, de 22 de setembre de 2015, en què va desestimar la pretensió articulada per la part actora de suspendre la resolució administrativa impugnada, en seu de mesures cautelars. Davant de tal denegació de suspensió, es va interposar un recurs d'apel·lació per part de la representació de la part actora, en el termini prefixat en la Llei jurisdiccional de 1998, i se li va donar el tràmit processal adequat, al qual es van oposar les direccions lletrades de les parts demandada i codemandada. Finalment, per provisió del TSJIB, es va assenyalar, per a la votació i decisió, el dia 26 de juliol de 2016, i la Sala accepta en part els raonaments jurídics que empra la interlocutòria d'instància i en la seva totalitat la decisió a la qual arriba.

La qüestió central rau en l'adopció o no de mesures cautelars davant d'ordres de demolició, ja que la revisió jurisdiccional ho era de la resolució dictada per la batllia de l'Ajuntament de Sant Joan de Labritja (Eivissa), el 23 de juliol de 2012, que resolia i desestimava el recurs de reposició interposat contra la resolució d'expedient sancionador i de reposició de la legalitat urbanística contra l'entitat AIBS DOS CORTIJO DOS, S.L. Aquest recurs posteriorment fou ampliat a l'Ordre de 28 d'abril de 2015, que imposa la demolició immediata de les obres dutes a terme en virtut del Decret de batllia de 25 de maig de 2012, que concedia a la propietat un termini d'un mes per executar ella mateixa l'esmentada demolició. Aquí, no obstant això, ens movem en el si d'una peça separada de suspensió i en què l'entitat actora, mitjançant escrit separat al del recurs contenciós administratiu inicial, va interessar, precisament, la suspensió els efectes del decret recorregut i de tots els que es poguessin dictar en la seva execució, en especial el del dia 28 d'abril de 2015.

Dit això, i no obstant això, cal donar resposta al que és, en definitiva, el motiu de la controvèrsia i si és o no susceptible adoptar la mesura cautelar interessada. Tal com ens recorda la Interlocutòria de la Secció 7a de la Sala Tercera del Tribunal Suprem, de 23 de novembre de 2004, la jurisprudència ha delimitat la naturalesa i l'abast de les mesures cautelars. La doctrina del Suprem afirma que «la jurisprudència del Tribunal Constitucional (en STC 22/84 , 66/84, 238/92, 148/93, i la de 13 d'octubre de 1998, en resoldre el recurs d'empara núm. 486/97) ha reconegut el principi d'autotutela administrativa, que no és incompatible amb l'article 24.1 de la CE, enllaça amb el principi d'eficàcia previst a l'article 103.1 de la CE i se satisfà facilitant que l'execució se sotmeti a la decisió d'un Tribunal i aquest resolgui sobre la suspensió». Igualment s'afirma en 
seu constitucional que "[e]n reiterada doctrina d'aquesta Sala, al voltant del principi d'eficàcia de l'activitat administrativa (article 103.1 de la Constitució), i al de la presumpció de validesa dels actes administratius (article 57 de la Llei 30/92, de 26 de novembre, precepte que no ha estat modificat per la Llei 4/99), la regla general és l'executivitat immediata dels actes i disposicions i la possibilitat de suspensió es produeix quan s'originin perjudicis de reparació impossible o difícil». D’altra banda, l'aplicació del principi d'efectivitat de la tutela judicial (article 24.1 de la Constitució) «imposa el control jurisdiccional sobre l'activitat administrativa (article 106.1 de la Constitució) i, en tot cas, han de coordinar-se i harmonitzar l'evitació del dany als interessos públics que pugui derivar-se de la suspensió de l'execució i que en executar-se l'acte es causin perjudicis d'impossible o difícil reparació per a la part recurrent, que implica un judici de ponderació, com ha assenyalat aquest Tribunal (en les interlocutòries de 15 de gener, 21 de febrer, 28 de febrer, 14 i 18 de març, 8 d'abril, 18 de juliol i 8 de novembre de 1994, 1 d'abril, 22 de maig, 19 de setembre i 13 de desembre de 1995, 20 de juliol i 7 de novembre de 1996 i 16 de setembre de 1997)".

D’altra banda, el TSJIB en alguna sentència (com la número 249, de 19 de març de 2013), va establir la jurisprudència següent:

També hem d'assenyalar que en la valoració de la mesura cautelar sol·licitada cal, en primer lloc, que la part aporti una prova complerta de l'acreditació del perjudici greu i irreparable, ja que la mera enunciació d'aquest perjudici no suposa tal acreditació. No en va i de l'article 129 de la Llei de la jurisdicció contenciosa administrativa es desprèn, la mesura cautelar és l'excepció a la indiscutible executivitat de l'acte administratiu dimanant de la presumpció de legalitat i encert de què gaudeix. Per tant, és càrrega probatòria del sol-licitant aquest extrem.

En segon lloc, el coneixement de la peça separada de la mesura cautelar suposa un coneixement limitat de la qüestió, ja que és impossible l'anàlisi de fons o substantiva, i s'ha de limitar únicament a l'examen dels perjudicis que l'executivitat de l'acte ofereix a la part recurrent. Això no exclou que com a criteri que cal valorar per a la possibilitat de la concessió de la mesura, s'examini l'aparença de bon dret que exerceix la part recurrent. Encara que sempre amb el limitat caràcter que la peça separada de mesura cautelar exigeix i sense poder prejutjar el fons de l'assumpte.

En tercer lloc, és fonamental el criteri del periculum in mora, això és, l'assegurament del procés que passa per la valoració que l'executivitat de l'acte pugui produir una situació que converteixi en inviable el recurs contenciós, fent-li perdre la seva finalitat, fins i tot en el cas que veiés prosperar la tesi la part demandant. 
Igualment, en la Sentència número 126, de 5 de març de 2014, es va afirmar que:

Finalment ha de ponderar-se la intensitat que l'interès general demana de l'execució immediata de l'acte; i reitera fins a la sacietat la jurisprudència "quan les exigències d'execució que l'interès públic presenta són tènues n'hi haurà prou amb perjudicis d'escassa entitat per provocar la suspensió; al contrari, quan l'altra exigència és de gran intensitat, només els perjudicis d'elevada consideració poden determinar la suspensió de l'execució de l'acte.

Doncs bé, ateses les anteriors consideracions, el Tribunal ja es trobava en condicions de donar resposta a la controvèrsia. D'una banda, ens trobem en presència d'una temàtica relativa a la disciplina urbanística, en què, aparentment —i aquesta qüestió es dilucida en el fons del litigi-, s'ha produït una pertorbació i vulneració de la legalitat urbanística. Però el que analitza la sentència aquí tractada és si procedeix o no adoptar mesures de suspensió de l'acte d'execució d'una demolició d'obres presumptament il·legals.

El Tribunal afirma que davant d'un cas d'aquestes característiques cal extremar, més que mai, les cauteles. Tanmateix, la sentència afirma que aquí la presumpció és en favor de l'Administració, que ha decidit adoptar una resolució després de la tramitació de l'oportú expedient amb intervenció i contradicció de les parts i ordres específiques de demolició. Aquesta ordre específica ja es visualitzava en la Resolució administrativa de 25 de maig de 2012 i sobre la qual el Jutjat d'Instància basava el fil argumental per desestimar la mesura cautelar interessada.

Les cauteles han de ser, preventivament, de més entitat, perquè si s'atorgués la mesura cautelar de suspensió amb els efectes pretesos, és a dir, el manteniment d'allò indegudament efectuat i després es considerés pels tribunals, en ratificar els actes administratius, que les obres no estaven emparades legalment, els perjudicis per a l'interès públic serien més greus. L’Administració està obligada a verificar el control administratiu, i si el dany és reparable econòmicament, preval l'interès general.

D’altra banda, segons el parer del Tribunal, aquí i ara no hi ha aparença de bon dret; al contrari. Ni, a més, la part recurrent ha estat capaç d'acreditar, ni tan sols de forma indiciària, els perjudicis reals que se li ocasionen amb el manteniment de la situació anterior al dictat de les resolucions administratives recorregudes, especialment donats els terminis transcorreguts. 
Tota aquesta argumentació condueix el TSJIB a desestimar el recurs d'apel·lació i a confirmar la doctrina pel que fa a mesures cautelars en controvèrsies relatives a la disciplina urbanística. 